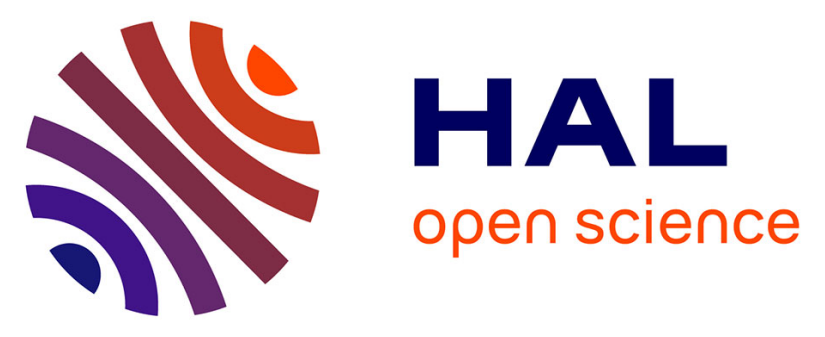

\title{
New perspectives on study designs for evaluating neuroprotection in Parkinson's disease
}

Laetitia Thibault, Olivier Rascol, Jean-Christophe Corvol, Joaquim Ferreira, Luc Defebvre, Dominique Deplanque, Regis Bordet, Caroline Moreau, David Devos

\section{To cite this version:}

Laetitia Thibault, Olivier Rascol, Jean-Christophe Corvol, Joaquim Ferreira, Luc Defebvre, et al.. New perspectives on study designs for evaluating neuroprotection in Parkinson's disease. Movement Disorders, 2017, Movement Disorders, 32 (10), pp.1365-1370. 10.1002/mds.27055 . hal-02150773

\section{HAL Id: hal-02150773 \\ https://hal.univ-lille.fr/hal-02150773}

Submitted on 7 Jun 2019

HAL is a multi-disciplinary open access archive for the deposit and dissemination of scientific research documents, whether they are published or not. The documents may come from teaching and research institutions in France or abroad, or from public or private research centers.
L'archive ouverte pluridisciplinaire HAL, est destinée au dépôt et à la diffusion de documents scientifiques de niveau recherche, publiés ou non, émanant des établissements d'enseignement et de recherche français ou étrangers, des laboratoires publics ou privés. 


\section{New perspectives on study designs for evaluating neuroprotection in Parkinson's disease}

\begin{tabular}{|r|l|}
\hline Journal: & Movement Disorders \\
\hline Manuscript ID & MDS-16-1139.R2 \\
\hline Wiley - Manuscript type: & Viewpoint \\
\hline Date Submitted by the Author: & n/a \\
\hline Complete List of Authors: & $\begin{array}{l}\text { Thibault, Laetitia } \\
\text { Rascol, Olivier; Faculty of Medicine Purpan, University UPS of Toulouse III, } \\
\text { Departments of Clinical Pharmacology and Neurosciences - CIC- } \\
\text { 9302/INSERM UMR825 } \\
\text { Corvol, Jean-Christophe; CIC Neurosciences, Department of Neurology } \\
\text { Ferreira, Joaquim; Faculty of Medicine, University of Lisbon, Laboratory of } \\
\text { Clinical Pharmacology and Therapeutics } \\
\text { Defebvre, Luc } \\
\text { Deplanque, Dominique } \\
\text { Bordet, Regis } \\
\text { Moreau, Caroline; roger salengro hospital, neurology } \\
\text { Devos, David; University of Lille Nord de France, Medical Pharmacology }\end{array}$ \\
\hline Keywords: & $\begin{array}{l}\text { Parkinson's disease, clinical trial, design, neuroprotection, disease } \\
\text { modifying treatment }\end{array}$ \\
\hline \multicolumn{2}{|c}{} \\
\hline
\end{tabular}




\section{Title Page}

\section{New perspectives on study designs for evaluating neuroprotection in Parkinson's disease}

Laetitia Thibault ${ }^{(1)}$, Olivier Rascol ${ }^{(2,3)}$ MD,PhD, Jean-Christophe Corvol ${ }^{(3,4)}$ MD, PhD, Joaquim Ferreira ${ }^{(5,6,7,8) \mathrm{MD}, \mathrm{PhD}}$, Luc Defebvre ${ }^{(9,10) \mathrm{MD}, \mathrm{PhD}}$, Dominique Deplanque ${ }^{(1,10,11) \mathrm{MD}, \mathrm{PhD}}$, Régis Bordet $^{(10,11) \mathrm{MD}, \mathrm{PhD}}$, Caroline Moreau ${ }^{(9,10) \mathrm{MD}, \mathrm{PhD}}$ and David Devos $(9,10,11) \mathrm{MD}, \mathrm{PhD}$

(1) Clinical Research Federation, Lille University Medical Center, Lille, France

(2) Department of Clinical Pharmacology and Neurosciences, CIC9302, Toulouse University Medical Center and Paul Sabatier University, Toulouse, France

(3) INSERM NS-PARK National Network, UMS 015, Toulouse, France

(4) Sorbonne Universités, UPMC Univ Paris 06, INSERM UMRS 1127, CIC 1422, CNRS UMR 7225, AP-HP and ICM, Hôpital Pitié-Salpêtrière, Département des maladies du système nerveux, Paris, France

(5) Clinical Pharmacology Unit, Instituto de Medicina Molecular, Faculty of Medicine, University of Lisbon, Portugal.

(6) Neurology Department, Hospital de Santa Maria, Centro Hospitalar Lisboa Norte, Portugal.

(7) CNS-Campus Neurológico Sénior, Torres Vedras, Portugal.

(8) Laboratory of Clinical Pharmacology and Therapeutics, Faculty of Medicine, University of Lisbon, Portugal.

(9) Department of Movement Disorders and Neurology, Lille University Medical Center, France

(10) University of Lille, INSERM U1171, Lille, France

(11) Department of Medical Pharmacology, Lille University Medical Center, France 
Corresponding author: Devos David, MD, PhD, Département de Pharmacologie Médicale, Université Lille Nord de France, CHRU de Lille, F-59037 Lille, France. david.devos@chrulille.fr

Financial Disclosure/Conflict of Interest concerning the research related to the manuscript: none

Running title: New perspectives on study designs for neuroprotection in PD

Keywords: Parkinson's disease - treatment- clinical trial - design - neuroprotection disease-modifying effect.

Title: 87 characters including space, running title: 60 characters including space, 1998 words (abstract: 250 words); Tables: 1; Figure: 1; references: (Viewpoint: 1-29; Supplementary Material: 30-78)

Supplementary Material:

- S-Previous designs

- S-Figure 1

- S-Table 1

- S-Table 2 


\section{Abstract (optional)}

None of the currently available pharmacologic treatments for Parkinson's disease (PD) has demonstrated neuroprotective effects in clinical trials. Of the many factors that might account for this failure (including complex disease mechanisms and the medications' pharmacodynamic limitations), some may be related to the choice of the trial design. Here, we review clinical trial designs and make a number of recommendations concerning the choice of the trial design as a function of the clinical development phase. We searched the PubMed and ClinicalTrials.gov databases for previous and ongoing clinical trials related to neuroprotection and/or a disease-modifying effect in PD. We highlight adaptations of these designs and suggest several potentially valuable new designs from outside the field of PD. A total of 38 completed studies and 9 ongoing studies in PD were analyzed, along with 3 completed studies outside the field of PD. We suggest that Phase II should start with a futility design or a double (or single-blind with blind rating) parallel-group trial; depending on the drug's action, it could be a molecularly targeted therapy. Next, a simple withdrawal design could be used to assess dose ranging and symptomatic effects. A drug with a known symptomatic effect should be studied in a relatively long-term, randomized withdrawal trial and not in a delayed-start paradigm. A Phase III randomized withdrawal trial with three groups and two 6-month periods may be a judicious choice. The final step would require a specific long-term design in which the time to achievement of various PD milestones is analyzed. 


\section{INTRODUCTION}

Parkinson's disease (PD) is a progressive neurodegenerative disease that affects millions of people around the world. PD is a neuropsychiatric disease characterized by both motor and non-motor symptoms.[1, 2, 3] The pathological hallmarks are the loss of dopaminergic neurons in the substantia nigra pars compacta, iron overload and alpha synuclein aggregates in the remaining dopaminergic cells.[4] By the time symptoms of PD appear, patients have lost 80 percent of their striatal or putaminal dopamine.[5] At present, there is no cure for PD; the available treatments are primarily symptomatic, and are essentially based on the restoration of dopaminergic transmission.[6] The concept of neuroprotection has been defined as the capacity to slow down, stop or reverse the course of the disease by protecting neurons against degeneration. Since there is no means of counting the number of remaining neurons in live patients, the concept of disease modification has been introduced. Although some encouraging preclinical data suggest that neuronal loss can be slowed, the clinical trial data have been largely disappointing.[7,8]

Many factors could account for this failure (such as poorly understood disease mechanisms, and a medication's pharmacokinetic and pharmacodynamics limitations) but some may be related to the choice of the clinical trial design. Another factor is the placebo effect observed in clinical studies; consequently, a large sample size is required.[9] Moreover, slow disease progression means that long-term, expensive studies are needed to detect a significant effect. Furthermore, it has already been pointed out that a drug's symptomatic effect might mask a putative disease-modifying effect.[10,11] Lastly, the development of neuroprotective drugs is restricted by the lack of reliable biomarkers.

In view of this lack of success, greater attention must be paid to selecting the most appropriate clinical trial design. This Viewpoint highlights adaptations of designs previously used in PD and also suggests the novel application of trial designs taken from outside the field of PD. Lastly, we make several recommendations for the assessment of disease-modifying drugs at each phase of clinical development.

\section{NEW DESIGNS}

Trial designs previously used in PD (i.e. the futility design, the simple withdrawal design, the delayed-start design, and the simple long-term study) are presented in the online Supplementary Material and S-Figure 1. Previous and ongoing clinical trials intended to evidence neuroprotection are listed in S-Table 1. 


\section{Randomized withdrawal designs \\ Randomized withdrawal designs with three groups}

This design has already been described [12] but has never been used in PD (Figure 1a). Given that its two control groups (placebo/placebo and treatment/treatment) can be compared with the treatment/placebo group, this design is better that the simple withdrawal or delayedstart designs for differentiating between symptomatic effects and disease-modifying effects. However, the presence of an additional (third) group in this promising design decreases the power of the statistical analysis and thus requires a larger total sample size (i.e. by about one third). Thus, recruitment may be more challenging and more expensive.

\section{Randomized withdrawal of all the patients}

This constitutes a novel adaptation of the simple withdrawal design but has never been used to study neuroprotection. All patients having received active treatment during period 1 are then randomized to further active treatment or to a placebo for period 2 (Figure 1b). Treating all the patients in period 1 has two advantages: (i) there is no concern about loss of blinding, and (ii) the patients spend less time on placebo (less ethical concerns). Lastly, this design might be a good option if the treatment is thought to have a large symptomatic effect as well as a disease-modifying effect.

\section{Randomized withdrawal of the responders}

In this variation of design, only patients classified as responders during period 1 are randomized to further active treatment or placebo during period 2 (Figure 1c). This design has been used in Phase III trials on patients with orthostatic hypotension [13], schizophrenia [14] and pediatric bipolar I disorder [15] but has never been applied to neuroprotection. This would be an interesting way of assessing a drug with a large symptomatic effect or with a specific, known mechanism of neuroprotection linked to reliable biomarkers. The a priori definition of responders can be based on clinical criteria and/or a particular genetic or pharmacogenetic profile. Thus, the drug's effect could be studied in a specific group of PD patients in which it is expected to have the greatest possible effect. However, this design is associated with several limitations in PD, such as the lack of an established definition of a responder, and the risk of overestimating a drug's effect in a subgroup relative to the effect in the patient population as a whole. Furthermore, a large total number of patients may have to be recruited to obtain a sufficient subpopulation of responders. 


\section{Specific long-term designs}

The demonstration of a long-term effect requires a high level of efficacy and a very large study population, which may only be achievable in Phase III studies. A simple, long-term design has nevertheless been used to demonstrate neuroprotection; the study endpoints were a change in the UPDRS score and the need for symptomatic treatment. [16,17] However, these endpoints were not standardized because the investigators themselves decided when the participants required symptomatic treatment. In the future, these problems could be circumvented by defining the point at which symptomatic treatment is initiated in de novo patients.

\section{A specific long-term design in a strict protocol}

Patients having been randomized to placebo or active treatment during period 1 are not allowed to take symptomatic medications for a predetermined length of time (Figure 1f). The length of period 1 is the same for all patients. During period 2, the patients stay in their study groups but are allowed to take symptomatic medications. Patients who need rescue medications during period 1 are withdrawn from the study.

\section{A specific long-term design in an open protocol}

Patients receive the symptomatic drug only when they have reached a specific milestone; the length of each period is not predefined. Hence, a specific "time to event" (i.e. the time needed to reach the milestone) is the primary criterion. (Figure $1 \mathbf{d , e}$ ). The time to event can be calculated for each patient, and then the two groups can be compared. A longer time interval in the group having received the investigational drug is suggestive of a long-term effect (Figure 1g).

\section{Strict or open protocols?}

These long-term designs might be more valuable than the delayed-start design or withdrawal designs because patients are treated with a symptomatic medication during the second period, and therefore avoid being undertreated for too long. Thus, the study itself can be planned over a longer period of time. Moreover, these designs differ from the simple long-term study in that the recruited patients are still assessed in a double-blind manner when they receive symptomatic treatment during the second period. 
The statistical analysis is easier with a strict protocol than an open protocol because the length of period 1 is the same for all patients. However, there are some sources of potential bias; in particular, some patients may not require symptomatic treatment at the start of period 2 or may have to withdraw when they need symptomatic treatment during period 1. Moreover, the length of period 1 is difficult to determine. Conversely, the fact that the open protocol is better suited to each patient's needs should reduce the drop-out rate. However, the specific "time to event" that triggers the initiation of symptomatic medication must be carefully determined. Moreover, the average intergroup differences in an open design will be much smaller than in a strict protocol because changes in symptomatic treatment will diminish the ability to observe a treatment effect. Thus, the sample size would have to be larger and the trial period would have to be longer.

\section{RECOMMENDATIONS}

The designs' respective strengths and limitations are summarized in the online Supplementary Material (S-Table 2).

\section{Choice of the design as a function of the clinical development phase (Table 1) Design}

A Phase I safety trial can be followed by a Phase II non-superiority trial, in order to test a drug over a short period in a small number of patients. This futility design could be considered for a pilot trial. Alternatively, the first Phase II trial could adopt a conventional, double- or single-blind (e.g. with blind video rating) parallel-group design. The novel concept of molecularly targeted therapies might also be of value if the drug is known to act preferentially in a particular pharmacogenetic context. This would reveal the drug's maximum efficacy in the corresponding subpopulation of patients.

Next, a straightforward simple withdrawal design would be useful for dose-ranging studies. To evidence different dose-effects and determine its nature (i.e. symptomatic vs. diseasemodifying), the primary endpoint should be analyzed at the end of period 1 . The withdrawal period provides initial evidence of a disease-modifying effect, without taking a risk on the whole protocol. Alternatively, the randomized withdrawal of patients who respond to a known symptomatic stimulus might be an interesting way of assessing a concomitant diseasemodifying effect.

The detection of a disease-modifying effect requires large, long, proof-of-concept studies in Phase II or at the start of Phase III. A drug with a known symptomatic effect should be 
studied in a relatively long, randomized withdrawal trial, rather than in a delayed-start paradigm. A drug lacking an observed symptomatic effect in initial studies would not require a two-period trial design. A randomized withdrawal trial with three groups and two 6-month periods might evidence a disease-modifying effect more effectively but would constitute a large Phase III trial.

Ideally, the clinical development program should end with the demonstration of a diseasemodifying effect (i.e. the time to various PD milestones). This would require a specific longterm design of 24-36 months.

\section{Target population}

De novo patients constitute the best population, so that the remaining dopaminergic neurons (often $50 \%$ of the normal number at diagnosis and less than $30 \%$ loss three years later) can be saved.[18, 19] Furthermore, there is no bias caused by the effects of dopaminergic treatment. However, this population is difficult to recruit and thus requires a long enrollment period. Moreover, there is a risk of including patients with atypical forms of parkinsonism. [20, 21] Conversely, patients treated in the early stages of the disease (i.e. $30 \%$ of remaining neurons at 3 years of disease progression) are easier to recruit than de novo patients and thus could be considered in the very first Phase II trial. [22] This population must be receiving a stable, moderate-dose regimen with a dopamine agonist and/or L-dopa.

\section{Duration of the trial}

The ADAGIO trial [23] provided valuable information on the duration of the treatment-free period: a period of 9 months in de novo patients was associated with a drop-out rate of 1015\%. A shorter period (e.g. 6 months) would reduce the drop-out rate but would also decrease the study's ability to detect an effect. A shorter period might be suitable for early clinical development. Conversely, a larger trial would have a greater chance of success with a 9month period. The length of period 2 represents a compromise between the minimum drug wash-out time and the duration of period 1, since the patients would have to go for a long time without symptomatic treatment.

\section{The primary criterion for evaluation}

Radiologic and biological endpoints (iron overload [24, 25, 26], atrophy [25], and loss of presynaptic nigrostriatal projections $[27,28]$ ) might be options for early development but they are not yet validated biomarkers. 
The total MDS-UPDRS score is a more suitable primary endpoint because it accurately measures motor and non-motor symptoms. It has already been used in a few neuroprotection trials[29]. However, the MDS-UPDRS part III score might be a good primary endpoint for an early Phase II trial because the motor handicap is less variable than the total handicap, which would reduce the number of patients required.

Although quality of life (as rated with the specific Parkinson's Disease Questionnaire-39) is strongly correlated with the MDS-UPDRS score and symptomatic benefit, it is unlikely to be a suitable primary endpoint when seeking a disease-modifying effect - at least in early clinical development. 


\section{Acknowledgment}

We thank Dr. David Fraser (Biotech Communication, Damery, France) for editorial assistance. The authors thank the French Ministry of Health for funding PHRC grants; the DN2M regional fund; the French Parkinson's Disease Association, and the French charity ARSLA.

\section{Authors' roles}

1) Research project: A. Conception, B. Organization, C. Execution;

2) Statistical Analysis: A. Design, B. Execution, C. Review and Critique;

3) Manuscript: A. Writing of the first draft, B. Review and Critique.

LT: $1 \mathrm{ABC}, 3 \mathrm{~A}$

OR: 1A, 3B

JCC: 1A, 3B

JF: $3 \mathrm{~A}$

LD: $3 \mathrm{~A}$

DDep: 3A

RB: $3 \mathrm{~A}$

CM: 3A

DDev: $1 \mathrm{~A}, \mathrm{BC}, 3 \mathrm{~A}, \mathrm{~B}$

\section{Financial Disclosures of all authors (for the preceding 12 months)}

Ms Thibault has nothing to disclose.

Dr. Moreau has received a grant from France Parkinson. She has also received honoraria for lectures at symposia from Abbvie and Medtronic.

Prof. Defebvre served on several Scientific Advisory Boards for Abbvie and Zambon. He has received various honoraria from pharmaceutical companies for consultancy and lectures on Parkinson's disease at symposia.

Prof. Devos served on several Scientific Advisory Boards for Novartis, Aguettant, Orkyn, and has received PHRC grants from the French Ministry of Health and research funding from the France Parkinson and ARSLA charities. He has received various honoraria from pharmaceutical companies for consultancy and lectures on Parkinson's disease at symposia. 
Jean-Christophe Corvol received research grants from INSERM and APHP and received speaker's honoraria and travel reimbursements from Lundbeck, Biogen and Schering-Plough.

Olivier Rascol has received research grants from the CHU de Toulouse, France-Parkinson, INSERM-DGOS (the Translational Research program), the French Ministry of Health (the PHRC program), Lundbeck, TEVA and UCB. He has served on advisory boards, served as a consultant and given lectures for pharmaceutical companies such as Abbott, Addex, BIAL, Boehringer-Ingelheim, Impax Pharmaceuticals, Lundbeck, Merck, Merck-Serono, Novartis, Oxford Biomedica, TEVA, UCB and Xenoport.

Régis Bordet receives funding from the French Ministry of Research. He has received various honoraria from pharmaceutical companies for consultancy and lectures at symposia.

JJF has held consultancy functions with GlaxoSmithKline, Novartis, Teva, Lundbeck, Solvay, Abbott, BIAL, Merck-Serono, Merz, Ipsen, and Biogen; has received lecture fees from Biogen and BIAL; has received grants from GlaxoSmithKline, Grünenthal, MSD, Allergan, Novartis, Fundação MSD (Portugal), and Teva; and has been employed by Centro Hospitalar Lisboa Norte, Faculdade de Medicina de Lisboa. 


\section{References:}

1. Chaudhuri KR, Yates L, Martinez-Martin P. The non-motor symptom complex of Parkinson's disease: A comprehensive assessment is essential. Curr Neurol Neurosci. 2005; Rep 5: 275-283

2. Langston JW. The Parkinson's complex: Parkinsonism is just the tip of the iceberg. Ann Neurol. 2006; 59: 591-596.

3. Jain S. Multi-organ autonomic dysfunction in Parkinson disease. Parkinsonism Relat Disord. 2011; 17: 77-83.

4. Dauer W, Przedborski S. Parkinson's disease: Mechanisms and models. Neuron. 2003; 39: 889-909.

5. Dauer W, Przedborski S. Parkinson's disease: mechanisms and models. Neuron. 2003;39:889-909

6. Fahn S. Parkinson disease, the effect of levodopa, and the ELLDOPA trial. Arch Neurol. 1999; 56:529-35.

7. Olanow CW, Kieburtz K, Schapira AH. Why have we failed to achieve neuroprotection in Parkinson's disease? Ann Neurol. 2008; 64(suppl 2):S101-S110.

8. Lang AE, Melamed E, Poewe W, Rascol O. Trial designs used to study neuroprotective therapy in Parkinson's disease.Mov Disord. 2013; 28:86-95.

9. Ko JH, Feigin A, Mattis PJ, Tang CC, Ma Y, Dhawan V, During MJ, Kaplitt MG, Eidelberg D. Network modulation following sham surgery in Parkinson's disease. J Clin Invest. 2014;124:3656-66.

10. Fahn S, Oakes D, Shoulson I, et al. Levodopa and the progression of Parkinson's disease. N Engl J Med .2004; 351:2498-2508. 
11. Olanow CW, Rascol O, Hauser R, et al. A double-blind, delayed start trial of rasagiline in Parkinson's disease. N Engl J Med. 2009; 361: 1268-78

12. Michael P. McDermott, W.J. Hall, David Oakes, Shirley Eberly. Design and analysis of two-period studies of potentially disease-modifying treatments. Control Clin Trials. 2002; 23: 635-649

13. Biaggioni, Freeman R, J. Mathias C, Low P, Hewitt L.A, and Kaufmann H, on behalf of Droxidopa 302 Investigators. Randomized Withdrawal Study of Patients With Symptomatic Neurogenic Orthostatic Hypotension Responsive to Droxidopa. Hypertension. 2015 Jan; 65(1): 101-107.

14. Tandon, Cucchiaro J, Phillips D, Hernandez D, Mao Y, Pikalov A, Loebel A. A doubleblind, placebo-controlled, randomized withdrawal study of lurasidone for the maintenance of efficacy in patients with schizophrenia. J Psychopharmacol. 2016;30(1):69-77.

15. Findling RL, Chang K, Robb A, Foster VJ, Horrigan J, Krishen A, Wamil A, Kraus JE, DelBello M. Adjunctive Maintenance Lamotrigine for Pediatric Bipolar I Disorder: A Placebo-Controlled, Randomized Withdrawal Study. J Am Acad Child Adolesc Psychiatry. 2015;54:1020-1031.

16. Parkinson Study Group. Effects of tocopherol and deprenyl on the progression of disability in early Parkinson's disease. The New England Journal of Medicine. 1993; 32: 176-183.

17. Parkinson Study Group PRECEPT Investigators. Mixed lineage kinase inhibitor CEP1347 fails to delay disability in early Parkinson disease. Neurology. 2007; 69:1480-1490.

18. Marsden CD. Parkinson's disease. Lancet. 1990; 335:948-952

19. Ross GW, Petrovitch H, Abbott RD, et al. Parkinsonian signs and substantia nigra neuron density in decendents elders without PD. Ann Neurol. 2004; 56:532-539.

20. O. Rascol, "Disease-modification" trials in Parkinson disease: target populations, endpoints and study design. Neurology.2009; S51eS58.

21. Van der Schyf C.J., Rational drug discovery design approaches for treating Parkinson's disease, Expert Opin. Drug Discov. 2015; 713e741, 
22. Athauda D \& Foltynie T. Challenges in detecting disease modification in Parkinson's disease clinical trials. Parkinsonism Relat Disord. 2016; S1353-8020(16)30283-8

23. Olanow CW., Hauser RA., Jankovic J., Langston W., Lang A., Poewe W., Tolosa E., Stocchi F., Melamed E., Eyal E., \& Olivier Rascol. A Randomized, Double-Blind, Placebo-Controlled, Delayed Start Study to Assess Rasagiline as a Disease Modifying Therapy in Parkinson's Disease (The ADAGIO Study): Rationale, Design. Movement Disorder. 2008; 23, 2194-2201.

24. Tuite P. Magnetic resonance imaging as a potential biomarker for Parkinson's disease. Transl Res. 2015. pii: S1931-5244(15)00429-6.

25. Hopes L, Grolez G, Moreau C, Lopes R, Ryckewaert G, Carrière N, Auger F, Laloux C, Petrault M, Devedjian JC, Bordet R, Defebvre L, Jissendi P, Delmaire C, Devos D. Magnetic Resonance Imaging Features of the Nigrostriatal System: Biomarkers of Parkinson's Disease Stages? PLoS One. 2016;11:e0147947.

26. Devos D, Moreau C, Devedjian JC, Kluza J, Petrault M, Laloux C, Jonneaux A, Ryckewaert G, Garçon G, Rouaix N, Duhamel A, Jissendi P, Dujardin K, Auger F, Ravasi L, Hopes L, Grolez G, Firdaus W, Sablonnière B, Strubi-Vuillaume I, Zahr N, Destée A, Corvol JC, Pöltl D, Leist M, Rose C, Defebvre L, Marchetti P, Cabantchik ZI, Bordet R. Targeting chelatable iron as a therapeutic modality in Parkinson's disease. Antioxid Redox Signal. 2014; 10;21(2):195-210.

27. Varrone A, Halldin C. New developments of dopaminergic imaging in Parkinson's disease. Q J Nucl Med Mol Imaging. 2012;56:68-82

28. Pavese N, Kiferle L, Piccini P. Neuroprotection and imaging studies in Parkinson's disease. Parkinsonism Relat Disord. 2009;15 Suppl 4:S33-7.

29. Aviles-Olmos I, Dickson J, Kefalopoulou Z, Djamshidian A, Kahan J, Ell P, Whitton P, Wyse R, Isaacs T, Lees A, Limousin P, Foltynie T. Motor and cognitive advantages persist 12 months after exenatide exposure in Parkinson's disease. J Parkinsons Dis. 2014;4(3):337-44.

\section{References for the Supplementary Material:}

30. Elm JJ, Goetz CG, Ravina B, Shannon K, Wooten GF, Tanner CM, Palesch YY, Huang P, Guimaraes P, Kamp C, Tilley BC, Kieburtz K; NET-PD Investigators. A responsive outcome for Parkinson's disease neuroprotection futility studies. Ann Neurol. 2005; 57(2):197-203. 
31. Goetz CG, Poewe W, Rascol O, et al. The Unified Parkinson's Disease Rating Scale (UPDRS): status and recommendations. Mov Disord. 2003; 18:738-750.

32. Goetz CG., Tilley BC., Shaftman SR., Stebbins GT., Fahn S., Martinez-Martin P., Poewe W., Sampaio C., Stern MB., Dodel R, Dubois B., Holloway R., Jankovic J., Kulisevsky J., Lang AE., Lees A., Leurgans S., LeWitt PA., Nyenhuis D., Olanow CW., Rascol O., Schrag A., Teresi JA., van Hilten JJ., LaPelle N \& Movement Disorder Society UPDRS Revision Task Force. Movement Disorder Society-sponsored revision of the Unified Parkinson's Disease Rating Scale (MDS-UPDRS): scale presentation and clinimetric testing results. Movement Disorders. 2008; 23(15), 2129-70.

33. Ravina B, Fagan S, Hart R, et al. Neuroprotective agents for clinical trials in Parkinson's disease: a systematic assessment. Neurology. 2003; 60:1234-1240.

34. Leber P. Observations and suggestions on antidementia drug development. Alzheimer Disease and Associated Disorders. 1996; 10(Suppl 1), 31-35.

35. Parkinson Study Group. A controlled, randomized, delayed-start study of rasagiline in early Parkinson disease. Arch Neurol. 2004; 61:561-566.

36. Nutt JG., Carter JH., Lea ES \& Sexton GJ. Evolution of the response to levodopa during the first 4 years of therapy. Annals of Neurology, 2002; 51(6), 686-93.

37. D'Agostino RB Sr. The delayed-start study design. N Engl J Med. 2009; 24;361(13):13046.

38. Parkinson Study Group. Levodopa and the progression of Parkinson's disease. N Engl J Med. 2004; 351: 2498-2508.

39. Olanow CW., Hauser RA., Jankovic J., Langston W., Lang A., Poewe W., Tolosa E., Stocchi F., Melamed E., Eyal E., \& Olivier Rascol. A Randomized, Double-Blind, Placebo-Controlled, Delayed Start Study to Assess Rasagiline as a Disease Modifying Therapy in Parkinson's Disease (The ADAGIO Study): Rationale, Design. Movement Disorder. 2008; 23, 2194-2201.

40. Tetrud JW, Langston JW. The effect of deprenyl (selegiline) on the natural history of Parkinson's disease. Science. 1989; 245:519-522 
41. Shults CW, Oakes D, Kieburtz K, et al. Effects of coenzyme Q10 in early Parkinson disease: evidence of slowing of the functional decline. Arch Neurol. 2002; 59:1541-1550.

42. Whone A, Watts R, Stoessl J, et al. Slower progression of Parkinson's disease with ropinirole versus levodopa: the REALPET study: Ann Neurol. 2003; 54:93-101.

43. Snow BJ, Rolfe FL, Lockhart MM, et al. A double-blind, placebo controlled study to assess the mitochondria-targeted antioxidant MitoQ as a disease- modifying therapy in Parkinson's disease. Mov Disord. 2010; 15;25(11):1670-4.

44. Parkinson Study Group PRECEPT Investigators. Mixed lineage kinase inhibitor CEP1347 fails to delay disability in early Parkinson disease. Neurology. 2007; 69:1480-1490.

45. NINDS Exploratory Trials in Parkinson Disease (NET-PD) Investigators. Effect of Creatine Monohydrate on Clinical Progression in Patients with Parkinson Disease. A Randomized Clinical Trial. JAMA.2015; 10;313(6):584-93.

46. Lang AE, Gill S, Patel NK, et al. Randomized controlled trial of intraputamenal glial cell line-derived neurotrophic factor infusion in Parkinson disease. Ann Neurol. 2006; 59:459466.

47. Marks WJ Jr, Bartus RT, Siffert J, et al. Gene delivery of AAV2- neurturin for Parkinson's disease: a double-blind, randomised, controlled trial. Lancet Neurol. 2010; 9:1164-1172.

48. Myllylä VV, Sotaniemi KA, Vuorinen JA, Heinonen EH. Selegiline as initial treatment in de novo parkinsonian patients. Neurology. 1992; 42:339-343.

49. Parkinson Study Group. Effect of deprenyl on the progression of disability in early Parkinson's disease. N Engl J Med. 1989; 321: 1364-1371

50. Parkinson Study Group. Impact of deprenyl and tocopherol treatment on Parkinson's disease in DATATOP subjects not requiring levodopa. Ann Neurol. 1996; 39:29-36.

51. Olanow CW., Hauser RA., Gauger L., Malapira T., Koller W., Hubble J., Bushenbark K., Lilienfeld D \& Esterlitz J. The effect of deprenyl and levodopa on the progression of signs and symptoms in Parkinson's disease. Annals of Neurology. 1995; 38, 771-777. 
52. Pålhagen S, Heinonen EH, Hägglund J, et al. Selegiline delays the onset of disability in de novo parkinsonian patients. Swedish Parkinson Study Group. Neurology. 1998; 51:520 525

53. Pålhagen S, Heinonen E, Hägglund J, Kaugesaar T, Mäki-Ikola O, Palm R; Swedish Parkinson Study Group. Selegiline slows the progression of the symptoms of Parkinson disease. Neurology. 2006; 66(8):1200-6.

54. NINDS NET-PD Investigators. A randomized clinical trial of coenzyme Q(10) and GPI1485 in early Parkinson disease. Neurology. 2007; 68:20-28.

55. Effects of Coenzyme Q10 (CoQ) in Parkinson Disease (QE3). Clinicaltrials.gov. Available at: www.http://clinicaltrials.gov/ct2/show/NCT00740714. Accessed January 31, 2016.

56. A Fixed Dose, Dose Response Study for Ropinirole Prolonged Release in Patients with Early Stage Parkinson's Disease (TANDEM-662). Clinicaltrials.gov. Available at: https://clinicaltrials.gov/ct2/show/study/NCT01485172. Accessed September 12, 2016.

57. Parkinson Study Group. Pramipexole vs levodopa as initial treatment for Parkinson disease: A randomized controlled trial. Parkinson Study Group. JAMA. 2000; 284:19311938.

58. Parkinson Study Group. Dopamine transporter brain imaging to assess the effects of Pramipexole vs levodopa Parkinson disease progression. JAMA. 2002; 287:1653-1661.

59. Schapira A, Albrecht S, Barone P, et al. Immediate vs. delayed start pramiprexole in early Parkinson's disease: the PROUD study. Parkinsonism Relat Disord. 2009; 15: S2-S81

60. Schapira AHV, Albrecht S, Barone P et al. Rationale for delayed-start study of pramipaxole in Parkinson's disease: the PROUD study. Mov Disord 2010; 25: 1627-32.

61. Schapira AH, McDermott MP, Barone P, et al. Pramipexole in patients with early Parkinson's disease (PROUD): a randomized delayed-start trial. Lancet Neurol. 2013; 12:747-755.

62. Jankovic J, Hunter C. A double-blind, placebo-controlled and longitudinal study of riluzole in early Parkinson's disease. Parkinsonism Relat Disord. 2002; 8(4):271-6. 
63. Olanow CW, Schapira AH, LeWitt PA, et al. TCH346 as a neuroprotective drug in Parkinson's disease: a double-blind, randomised, controlled trial. Lancet Neurol. 2006; 5:1013-1020.

64. NINDS NET-PD Investigators. A randomized, double-blind, futility clinical trial of creatine and minocycline in early Parkinson disease. Neurology. 2006; 66:664-671.

65. Investigation of Cogane (PYM50028) in Early-stage Parkinson's Disease (CONFIDENTPD). Clinicaltrials.gov. Available at: www. http://clinicaltrials.gov/ct2/show/NCT01060878. Accessed January 31, 2016

66. The GPI 1485 Study Group. GPI 1485, a neuroimmunophilin ligand, fails to alter disease progression in mild to moderate Parkinson's disease. Mov Disord. 2006; 21:A1009

67. Study of the Effect of SR57667B on 18F-Dopa PET Imaging in Patients with Parkinson's Disease. ClinicalTrials.gov. Available at: https://clinicaltrials.gov/ct2/show/record/NCT00220272. Accessed February 21, 2016

68. Schneider JS, Sendek S, Daskalakis C, Cambi F. GM1 ganglioside in Parkinson's disease: results of a five year open study. J Neurol Sci. 2010; 292:45-51.

69. Schneider JS, Gollomp SM, Sendek S, Colcher A, Cambi F, Du W. A randomized, controlled, delayed start trial of GM1 ganglioside in treated Parkinson's disease patients. J Neurol Sci. 2013; 324:140- 148.

70. NINDS Exploratory Trials in Parkinson Disease (NET-PD) FS-ZONE Investigators. Pioglitazone in early Parkinson's disease: a phase 2, multicentre, double-blind, randomised trial. Lancet Neurol. 2015; 14(8):795-803.

71. N-Acetylcysteine for Neuroprotection in Parkinson's Disease (NAC PD). ClinicalTrials.gov. Available at: www.clinicaltrials.gov/ct2/show/NCT01470027. Accessed January 31, 2016

72. Aviles-Olmos I, Dickson J, Kefalopoulou Z, et al. Exenatide and the treatment of patients with Parkinson's disease. J Clin Invest 2013; 123(6):2730-6.

73. Trial of Exenatide for Parkinson's Disease (EXENATIDE-PD). ClinicalTrials.gov. Available at: https:/clinicaltrials.gov/ct2/show/NCT01971242. Assessed February 21, 2016

74. Conservative Iron Chelation as a Disease-modifying Strategy in Parkinson's Disease (FAIRPARKII). Clinical.trials.gov. Available at: https://clinicaltrials.gov/ct2/show/ NCT02655315. Assessed January 31, 2016. 
75. Disease-modifying Potential of Transdermal NICotine in Early Parkinson's Disease (NICPD). Clinical.trials.gov. Available at: https://clinicaltrials.gov/ct2/show/NCT01560754. Assesses September 13, 2016.

76. Efficacy of Isradipine in Early Parkinson Disease. ). Clinicaltrials.gov. Available at: https://clinicaltrials.gov/ct2/show/NCT02168842. Accessed September 13, 2016.

77. Uc EY, Doerschug KC, Magnotta V, Dawson JD, Thomsen TR, Kline JN, Rizzo M, Newman SR, Mehta S, Grabowski TJ, Bruss J, Blanchette DR, Anderson SW, Voss MW, Kramer AF,

78. Frazzitta G, Maestri R, Bertotti G, Riboldazzi G, Boveri N, Perini M, Uccellini D, Turla M, Comi C, Pezzoli G, Ghilardi MF. Intensive rehabilitation treatment in early Parkinson's disease: a randomized pilot study with a 2-year follow-up. Neurorehabil Neural Repair. 2015; 29(2):123-31. 


\section{Figures}

Figure 1. A randomized withdrawal study with three groups. There are two arms (placebo or treatment) during period 1 and three arms during period 2 . The green arrows indicate the mean change from baseline in the total MDS-UPDRS score during periods 1 and/or 2 . In theory, the design can differentiate between overall, symptomatic and disease-modifying effects. B. Randomized withdrawal with all patients. At the end of period 1, all patients are randomized to placebo or active treatment. C. Randomized withdrawal with responders only. Patients who respond to the treatment during period 1 are randomized to placebo or active treatment at the start of period 2.

D. A table showing examples of milestones in PD that can be used as the "time to event" and thus might be delayed by a disease-modifying drug. The milestones can be assessed accurately using a single MDS-UPDRS subscore or a combination of MDS-UPDRS subscores with a threshold of 2 or 3. E. A schematic illustration showing the progression of the functional state in the absence of treatment (grey line), in the presence of a symptomatic drug effect (blue line), and in the presence of a disease-modifying effect (green line). A symptomatic drug improves the functional state at the beginning of the treatment but the benefit is lost later on, and the disease progression is the same as it would be in untreated patients (the natural course of the disease). However, a disease-modifying drug can delay the time to each PD milestone (pink to red lines) and the time to event (black arrows). F. A longterm study with a strict protocol. De novo patients are randomized into the placebo group (in orange) or the active treatment group (in blue). The green arrows indicate the mean change in the MDS-UPDRS score over the two periods for each group. G. A long-term study with an open protocol. De novo patients are randomized into the placebo group (in orange) or the active treatment group (in blue). The trigger for symptomatic treatment (milestone 1, the 
dotted dark line) is a defined increase in handicap (e.g. by $15-20 \%$ ). For example, a patient in the placebo group receives symptomatic treatment at $\mathrm{T} 1$, whereas a patient in the active treatment group receives the symptomatic treatment at $\mathrm{T} 2$. If $\mathrm{T} 2$ is longer than $\mathrm{T} 1$, the disease progression is slower and the drug might have a disease-modifying effect. The histogram represents the mean time to reach the milestone 1 in the active treatment group or the placebo group. Patients in the active treatment group reach M1 less rapidly than the placebo group, so the treatment slows the disease progression and may thus have a disease-modifying effect.

Table 1. Suggested trial designs as a function of the clinical development phase. 
Table. 1 Suggested trial designs, as a function of the clinical development phase.

\begin{tabular}{|c|c|c|c|c|}
\hline Development phase & Design & Population & Primary criterion & Question \\
\hline $\begin{array}{l}\text { Initial Phase II } \\
\text { - Pilot trial } \\
\text { - Dose-ranging trial }\end{array}$ & $\begin{array}{l}\text {-Futility: for a pilot trial } \\
\text { - Simple withdrawal (6-9 months followed by } 15 \text { - } \\
30 \text { days) for a pilot or dose-ranging trial }\end{array}$ & $\begin{array}{l}\text { - 40-200 early- } \\
\text { stage, treated } \\
\text { PD patients }(<3 \\
\text { years since } \\
\text { diagnosis) } \\
\text { - Subpopulation } \\
\text { selected with a } \\
\text { molecular target }\end{array}$ & $\begin{array}{l}\text { Depending on the drug's action, } \\
\text { primary or secondary criteria can be: } \\
\text { - } \text { A radiologic or wet biomarker } \\
\text { (e.g. an MRI R2* sequence for iron, } \\
\text { a DaT scan, a PET scan, or } \\
\text { cerebrospinal fluid parameters) } \\
\text { - } \text { A molecular target (e.g. gene } \\
\text { mutation) } \\
\text { - MDS UPDRS part III score }\end{array}$ & $\begin{array}{l}\text { - Is there a treatment } \\
\text { effect } \text { vs. placebo? } \\
\text { - What is the } \\
\text { magnitude of a } \\
\text { symptomatic effect? } \\
\text { - Is there initial } \\
\text { evidence of a } \\
\text { disease-modifying } \\
\text { effect? }\end{array}$ \\
\hline $\begin{array}{l}\text { Large Phase II/III } \\
\text { trials } \\
\text { - Efficacy (proof of } \\
\text { concept) } \\
\text { - Initial Phase III } \\
\text { trial }\end{array}$ & $\begin{array}{l}\text { - For drugs with a symptomatic effect: } \\
\rightarrow \text { Randomized withdrawal with } 3 \text { groups } \\
\text { (two periods of } 6-9 \text { months) } \\
\rightarrow \text { Randomized withdrawal of all the patients (or } \\
\text { of the responders for a particular drug) } \\
\text { - For drugs with weak or no symptomatic effects: } \\
\rightarrow \text { Delayed start (two periods of } 6-9 \text { months) } \\
\rightarrow \text { Randomized withdrawal with } 2 \text { groups (two } \\
\text { periods of } 6 \text { months) } \\
\text { - For drugs with a short half-life: } \\
\rightarrow \text { Simple withdrawal ( } 9 \text { months, followed by } 1-2 \\
\text { months) }\end{array}$ & $\begin{array}{l}200-500 \text { de novo } \\
\text { patients }\end{array}$ & Total MDS UPDRS score & $\begin{array}{l}\text { Is there a disease- } \\
\text { modifying effect? }\end{array}$ \\
\hline Phases III trials & $\begin{array}{l}\text { A long term study with a fixed or open protocol } \\
\text { (24-36 months in the protocol, and then open-label } \\
\text { for up to } 5 \text { years) }\end{array}$ & $\begin{array}{l}400-1000 \text { de } \\
\text { novo patients }\end{array}$ & $\begin{array}{l}\text { PD milestones with assessment of } \\
\text { the time to event at } 24-36 \text { months } \\
\text { (primary endpoint) }\end{array}$ & $\begin{array}{l}\text { Is there a long-term } \\
\text { disease-modifying } \\
\text { effect? }\end{array}$ \\
\hline
\end{tabular}


Aagge 23 of 42

A

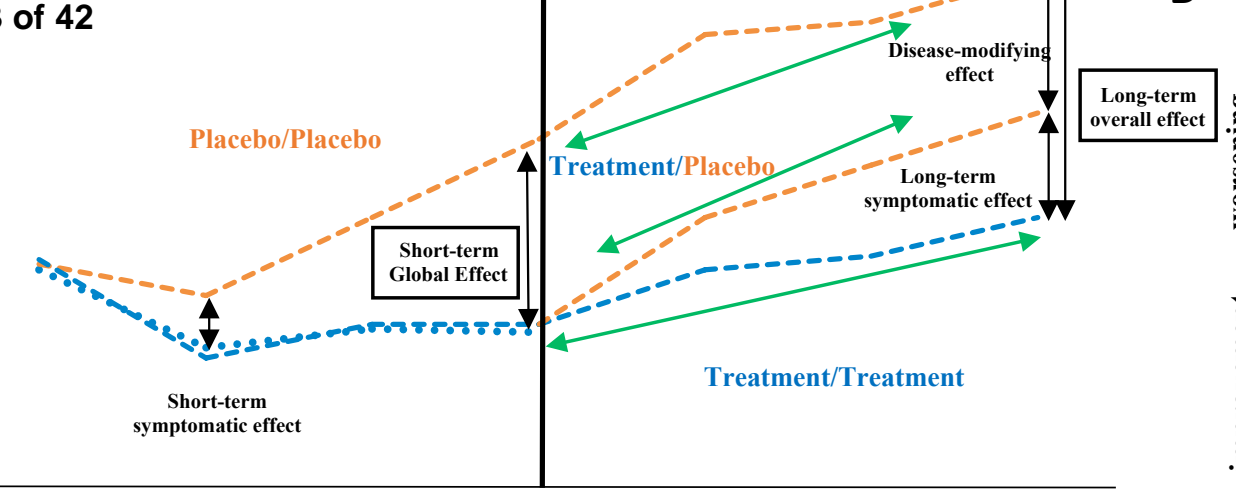

Period 1

Period 2

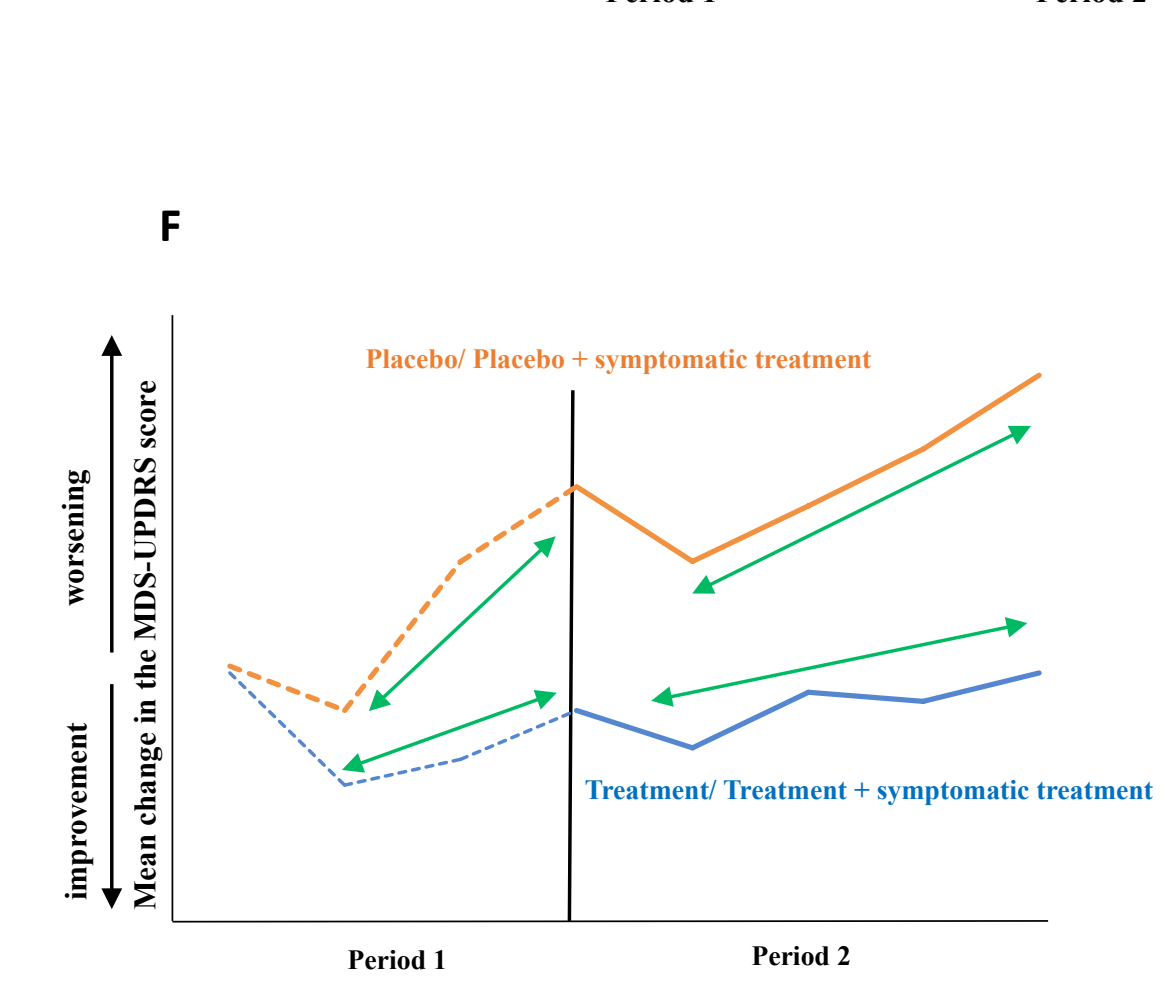

\section{Examples of milestones in PD}

Need for dopaminergic treatments

Slight impact on cognitive function

Slight impact on central nervous system

End-of-dose motor fluctuations

Dyskinesia (freezing postural instability)

Severe impact on cognitive or on behavior: dementia, hallucination, psychosis Severe impact on central nervous system Severe sleep disorders

24

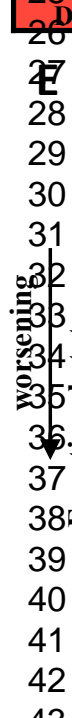

Symptomatic Effects of the drug:

treatment

Natural disease progression
Symptomatic effects only
Disease-modifying effect demonstrated by:

Diagnosis

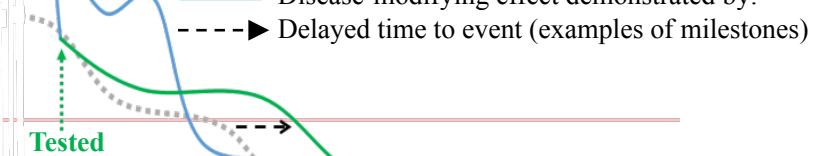
Tested

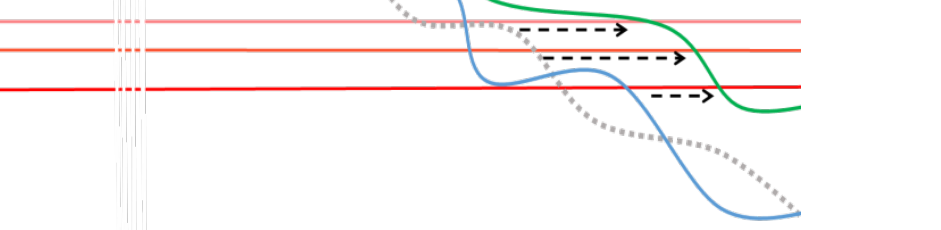

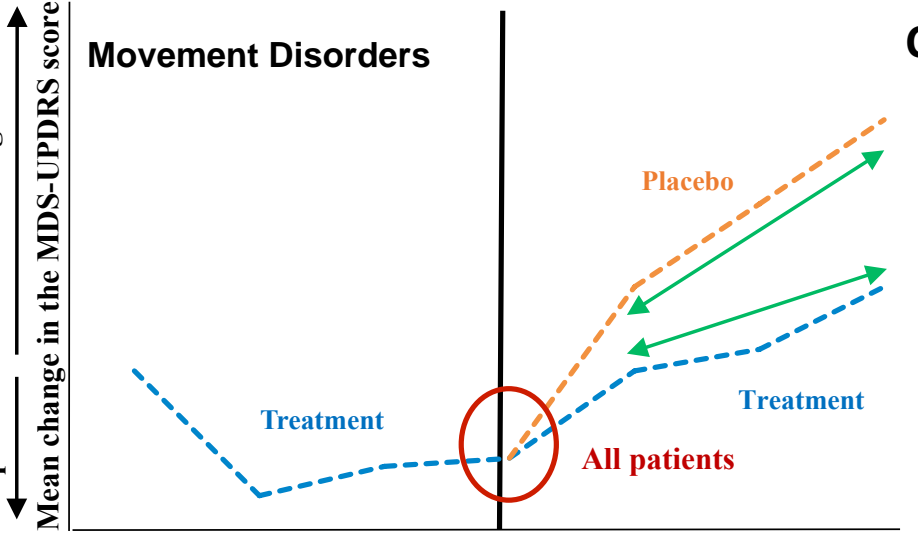

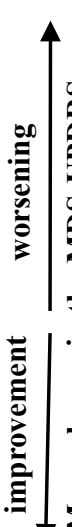

iod 1

Only responders

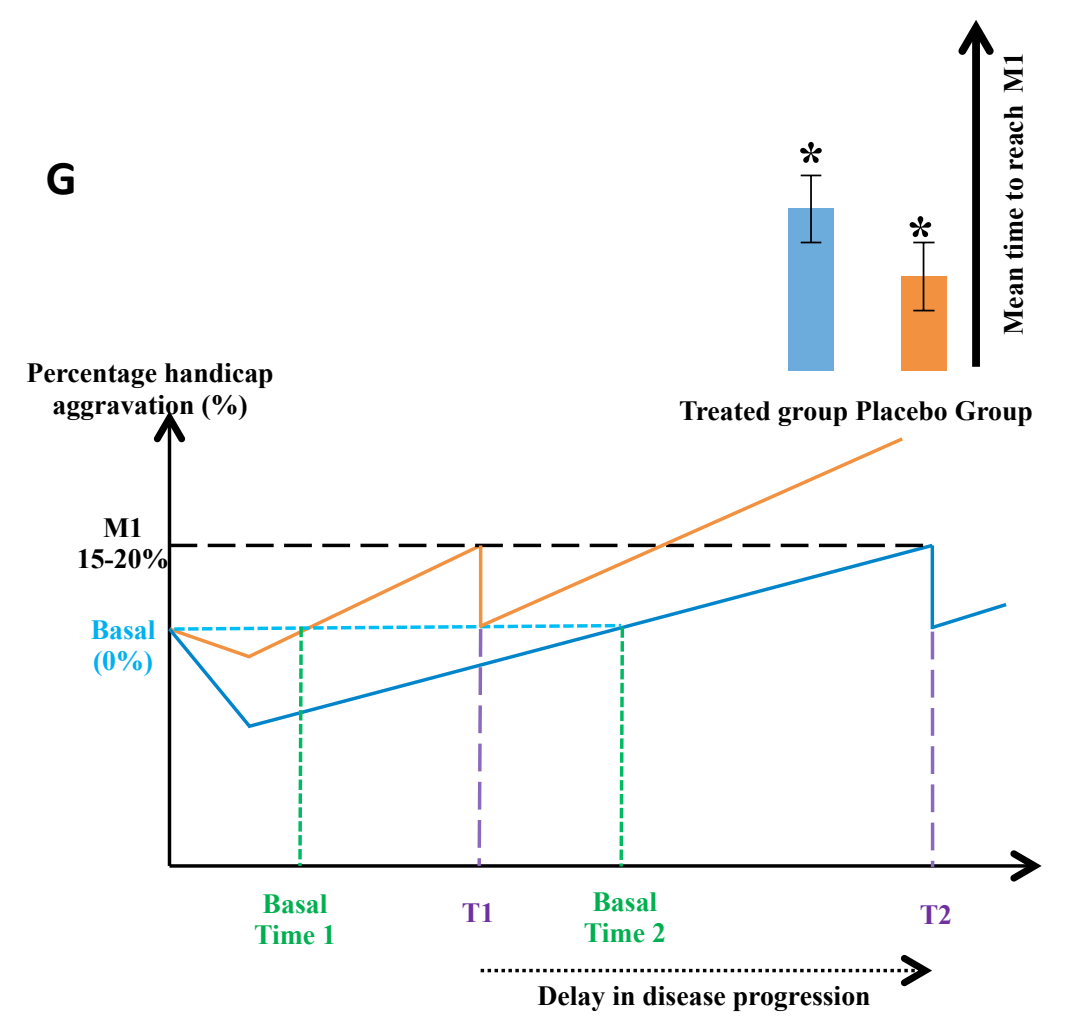




\section{Supplementary Material}

\section{Previous designs:}

\section{MATERIALS AND METHODS}

The present review was conducted by searching online databases, including Medline (via PubMed) and the ClinicalTrials.gov database. PubMed was searched using different logical combinations of keywords: "Parkinson's disease neuroprotection designs", "Parkinson's disease trial neuroprotection design", "Parkinson's disease modifier effect", and "Parkinson's disease clinical trials designs disease modification".

In an attempt to identify (i) randomized, controlled trials (RCTs) that had completed but had not been published at the time of this review and (ii) RCTs underway or being planned, we also searched the ClinicalTrials.gov online database. The following keywords were used: "Parkinson's disease modification", "Parkinson's disease slow disease course" and "Parkinson's disease", in combination with the names of drugs having already been used in other neuroprotection trials.

In order to check whether adaptions of the designs had already been used in other pathologies, we analyzed the following key words on PubMed: "randomized withdrawal study placebocontrolled double-blind patients", "long-term, two-period", "long-term study two-period design patients placebo-controlled", "long-term study two-period design patients time to event", and "long-term study two-period time to event".

There were no limitations on the publication date. However, only publications in English were considered.

\section{RESULTS}

The PubMed search identified a total of 908 articles, of which 87 concerned PD: "Parkinson's Disease neuroprotection designs" (18 records), "Parkinson's Disease trial neuroprotection design" (35 records), "Parkinson's Disease modifier effect" (29 records), "Parkinson's Disease clinical trials designs disease modification" (5 records).

After the exclusion of duplicates, preclinical studies and reviews, 44 publications (from 32 different clinical studies of neuroprotection) were analyzed. The ClinicalTrials.gov search (up until September 2016) identified 9 ongoing clinical trials studying possible disease modification in PD. 
Adaptations of the trial designs outside the field of PD were found in 832 records: "randomized withdrawal study placebo-controlled double blind patients" (782 records), "long-term, two-period" (38 records), and "long-term study two-period design patients placebo-controlled" (1 records). The searches containing the term "time to event" did not yield any hits.

\section{Previous designs (Table 2)}

\section{The futility design: the non-superiority study}

Randomized, controlled trials are costly and difficult to set up. A Phase I safety and tolerability trial can be followed by a non-superiority Phase II study in which the investigational drug is administered to a small number of patients over a short period of time. This design does not provide information on the treatment's putative efficacy and cannot differentiate between purely symptomatic and disease-modifying effects. However, it can indicate whether the treatment is worth assessing in an expensive RCT [30]. In a non-blinded futility study with a single treatment arm, the observed disease progression is compared with a predetermined lower limit of success (or an upper limit of worsening) in a single-sample test. The use of historical controls can give rise to bias. Firstly, the disease has to remain stable over the time and across the various trials and populations; this may not always be the case, especially since new diagnostic criteria (e.g. the Movement Disorders Society (MDS) criteria and the exclusion of DaT scans without evidence of dopaminergic deficit) and new therapeutic strategies (e.g. rasagiline in de novo PD patients) have been introduced. These modifications might influence the outcomes of future studies, relative to historical populations. Moreover, the rating scale used must be exactly the same, which will not be the case for PD (following the recent replacement of the UPDRS [31] by the MDS-UPDRS [32]). The non-superiority design was used by the National Institute of Neurological Disorders and Stroke to identify twelve possible neuroprotective agents, [33] and has been applied in many other trials in PD; however, these positive results have never been confirmed in subsequent randomized trials (S-Table 1).

To differentiate between purely symptomatic effects and a disease-modifying effect, a number of specific designs have been created. 


\section{The simple withdrawal design (see Figure 1a and its detailed legend)}

This design was first introduced in the field of Alzheimer's disease [34]. In a first (fixed) period (period 1), participants are randomly assigned to receive either active treatment or placebo. In a second period (period 2), all participants receive placebo. Period 1 should be long enough to observe the appearance of a change in disease progression but not long enough to create ethical problems and prompt a high drop-out rate. Period 2 should be long enough to eliminate (or "wash out") any symptomatic effects of the treatment administered during period 1. Active vs. placebo differences at the end of period 1 may be related to a symptomatic effect, a disease-modifying effect, or both. A better score at the end of period 2 in the group having received active treatment during period 1 can be attributed to a longerterm symptomatic effect or to a disease-modifying effect. This simple withdrawal design has been widely used (S-Table 1). In the ELLDOPA trial, participants were randomized to receive one of three dose levels of levodopa or a matching placebo for a 40 -week period, after which time the study medication was withdrawn for two weeks [35]. After this withdrawal period, participants receiving levodopa continued to have substantially better mean total UPDRS scores than those receiving placebo. However, the study's imaging data showed a lack of protection that was possibly related to levodopa's impact on the DaT scan. Moreover, the 2week withdrawal period was probably too short to totally wash out a residual effect of levodopa. Consequently, the disease-modifying effect of levodopa has not been demonstrated. The withdrawal design is simple, relatively inexpensive and non-biased. However, it requires knowledge of the investigational drug's pharmacological properties in general and its pharmacokinetic and pharmacodynamic half-lives in particular. For pharmacokinetic effects, the usual rule is that the withdrawal period (period 2) should last for at least five half-lives. The pharmacodynamic effect is more complex because it cannot be easily measured without a clinical assessment. Moreover, the dopaminergic effect of antiparkinsonian drugs can persist for several days to weeks after withdrawal, especially in early-stage disease [36]. It is always challenging to set the length of period 2, which is always a compromise between scientific and ethical considerations. Another limitation relates to the risk of not seeing a drug effect if period 1 is too short. Lastly, blinding is lost during period 2, which can induce a "nocebo" effect. 
In view of the ethical limitations associated with period 2 in the simple withdrawal design, another design has been developed.

\section{The delayed-start design (see Figure 1e and its detailed legend)}

In period 1, participants are randomized to placebo or active treatment. In period 2, all participants are given active treatment [37]. Again, active vs. placebo differences at the end of period 1 may be related to an effect on symptoms, a disease-modifying effect, or both. However, an intergroup difference at the end of period 2 argues in favor of a diseasemodifying effect. Indeed, effects on symptoms alone cannot readily explain persistent differences between the two groups at the end of period 2. This approach is based on the assumption that in trials that last for a year or more, symptomatic effects should be stable and similar in both groups at the end of the study. However, this assumption is not necessarily true. If there is a symptomatic effect in the long term, the group having received placebo in period 1 might never catch up with the other group. There are a number of other potential problems with this design. Indeed, the drop-out rate may differ in the two groups (e.g. with a higher rate in the placebo group) and thus impede the analysis [38]. The delayed-start design has been used in several trials (S-Table 1). The ADAGIO trial tested rasagiline's putative disease-modifying effect [39]. To obtain a positive result, the early-start treatment group had to meet three hierarchical endpoints in a primary analysis based on the UPDRS score. The study's results showed that early treatment with $1 \mathrm{mg}$ per day rasagiline provided benefits that were consistent with a possible disease-modifying effect but that early treatment with a higher dose ( $2 \mathrm{mg}$ per day) did not. Consequently, the presence of a disease-modifying effect remains subject to debate [37]. The ADAGIO results highlighted an important limitation of the delayed-start design (notably relative to the withdrawal design); at a high dose level, a drug's symptomatic effect may mask its disease-modifying effect. Moreover, this design (like the simple withdrawal design) suffers from a loss of blinding during period 1 for the early start group and during period 2 for the delayed-start group, which may lead to assessment bias. Since clinical scoring at the end of the study is crucial, these two unblinding periods might compromise the findings. Lastly, this study is expensive; the high potential drop-out rate over the long term means that a large number of patients must be included.

A third trial design has been used to study neuroprotection but cannot differentiate between symptomatic and disease-modifying effects. 


\section{$\underline{\text { The simple long-term study }}$}

Patients are randomized into parallel active versus placebo groups for a long period of time (usually several years, if the goal is to confirm a positive risk/benefit ratio). Long-term studies generally use global outcome measures, such as the overall level of handicap (motor and nonmotor) and quality of life. Positive effects on long-term, cumulative disability can still provide very useful evidence of disease modification. The long-term design has been widely used in clinical trials of early-stage and/or untreated patients with PD (S-Table 1) [40, 41, 42, 43, 44, $45]$ and in late-stage, treated patients with PD [46, 47]. However, it has not been possible to ascribe a positive outcome to a disease modifying effect alone. 
S-Figure 1. A. The simple withdrawal design. Patients are randomized into two groups. The first group receives placebo during periods 1 and 2, whereas the second group receives the active treatment in period 1 and then placebo in period 2. B. The delayed-start design. Patients are randomized into two groups. The first group (the early-start group) receives the active treatment during period 1 and period 2. The second group (the delayed-start group) receives placebo during period 1 and switches to active treatment during period 2 . The ADAGIO trial's three primary end points are shown. To determine a positive result with either dose, the early-start treatment group had to meet three hierarchical endpoints in a primary analysis based on the 176-point UPDRS (with a higher score indicating more severe disease): superiority over placebo in the rate of change in the UPDRS score between weeks 12 and 36 (green arrows), superiority over the delayed-start treatment in the change in the score between baseline and week 72 (red arrows), and non-inferiority with regard to the delayedstart treatment in the rate of change in the score between weeks 48 and 72 (purple arrows).

A

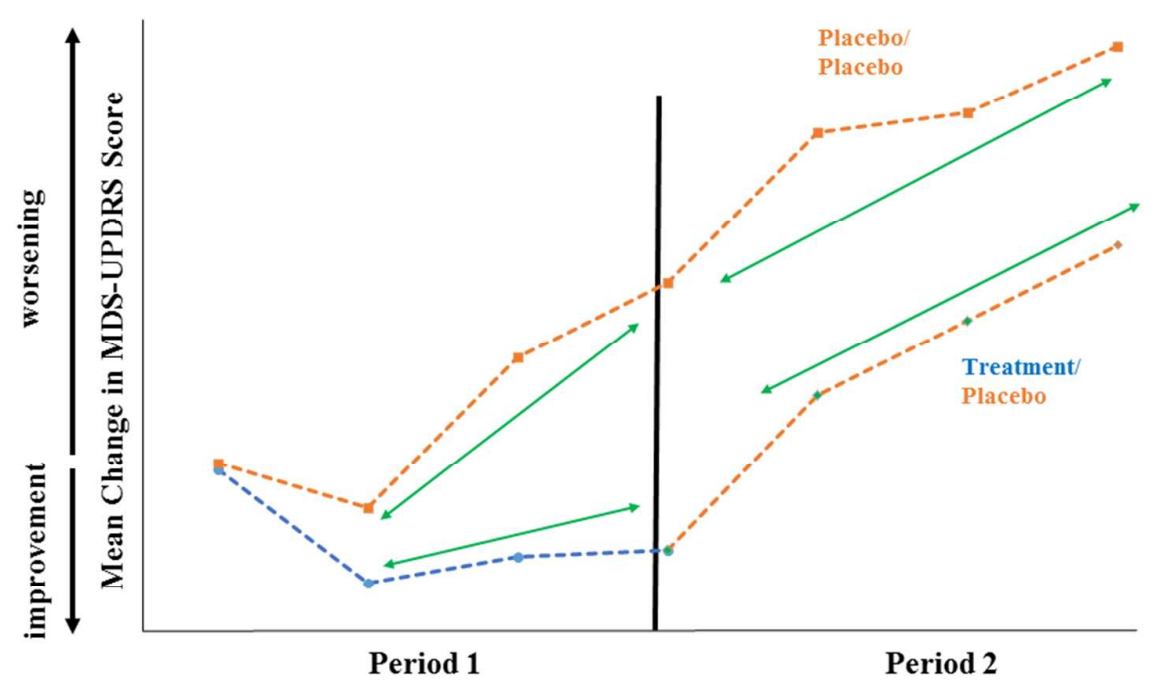

B

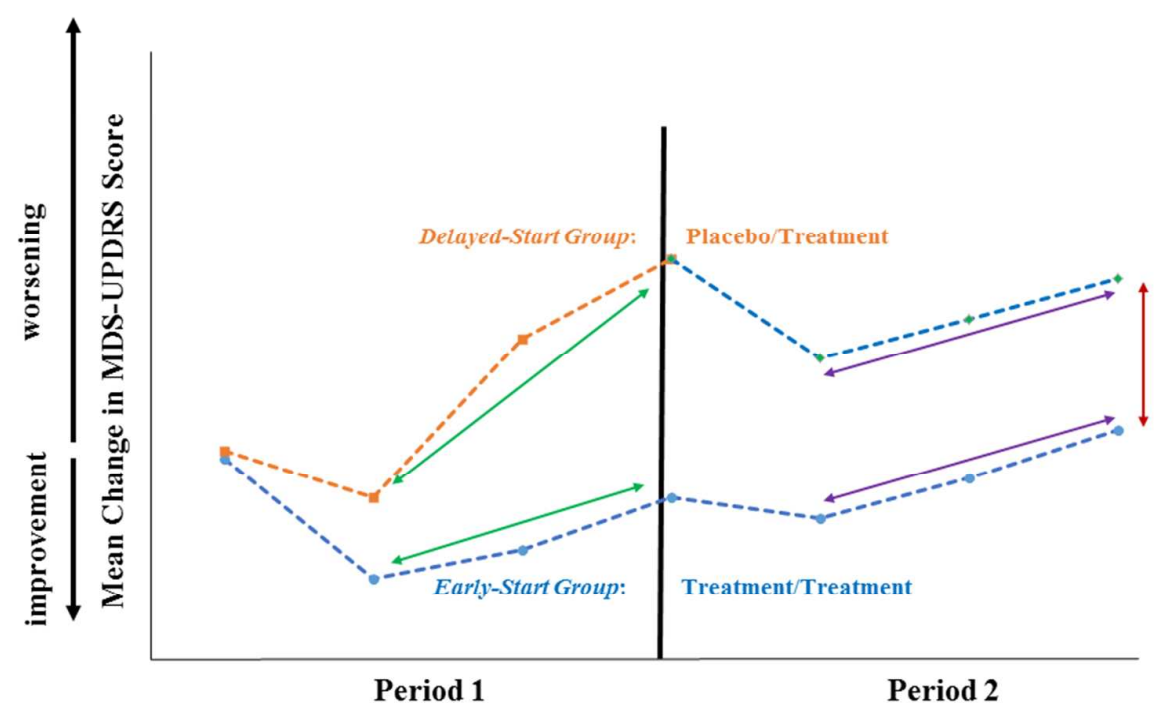


S-Table 1. Previous and ongoing clinical trials of putative disease-modifying treatments in PD.

\begin{tabular}{|c|c|c|c|c|c|c|c|}
\hline Drug & Study authors & $\begin{array}{l}\text { Design } \\
\text { (length) }\end{array}$ & PD population & $\begin{array}{l}\text { Primary } \\
\text { criterion for } \\
\text { evaluation }\end{array}$ & $\begin{array}{l}\text { Symptomatic } \\
\text { effect? }\end{array}$ & DM effect? & Comments/Limitations \\
\hline \multicolumn{8}{|c|}{ Pharmacological studies } \\
\hline \multirow[t]{5}{*}{ Selegiline } & $\begin{array}{l}\text { Tetrud JW, } \\
\text { Langston JW } \\
{[40]}\end{array}$ & LT (3 years) & $\begin{array}{l}54 \text { early-stage, } \\
\text { untreated patients }\end{array}$ & $\begin{array}{l}\text { The need for } \\
\text { symptomatic } \\
\text { treatment }\end{array}$ & Positive & Inconclusive & $\begin{array}{l}\text { The confounding symptomatic effects of selegiline were } \\
\text { not considered }\end{array}$ \\
\hline & $\begin{array}{l}\text { Myllylä et al., } \\
1992 \text { [48] }\end{array}$ & $\begin{array}{l}\text { LT (not } \\
\text { specified) }\end{array}$ & $\begin{array}{l}52 \text { early-stage, } \\
\text { untreated patients }\end{array}$ & $\begin{array}{l}\text { The change in } \\
\text { UPDRS }\end{array}$ & Positive & Inconclusive & $\begin{array}{l}\text { It is not clear whether the benefit of treatment was due to } \\
\text { a symptomatic effect alone or to a combination of } \\
\text { symptomatic and DM effects }\end{array}$ \\
\hline & $\begin{array}{l}\text { DATATOP } \\
\text { PSG. 1989, } \\
\text { [49] }\end{array}$ & LT (2 years) & $\begin{array}{l}800 \text { early-stage, } \\
\text { untreated patients }\end{array}$ & $\begin{array}{l}\text { The need for } \\
\text { symptomatic } \\
\text { treatment }\end{array}$ & Positive & Inconclusive & $\begin{array}{l}\text { It is not clear whether the benefit of treatment was due to } \\
\text { a symptomatic effect alone or to a combination of } \\
\text { symptomatic and DM effects }\end{array}$ \\
\hline & PSG $1996[50]$ & $\begin{array}{l}\text { Extension of } \\
\text { the } \\
\text { DATATOP } \\
\text { trial ( } 18 \\
\text { months with } 2 \\
\text { months of } \\
\text { WO before } \\
\text { the open-label } \\
\text { administration } \\
\text { of deprenyl) }\end{array}$ & $\begin{array}{l}310 \text { early-stage, } \\
\text { untreated patients } \\
\text { (DATATOP } \\
\text { subjects not } \\
\text { requiring levodopa). }\end{array}$ & $\begin{array}{l}\text { Disability } \\
\text { requiring } \\
\text { levodopa }\end{array}$ & Negative & Negative & $\begin{array}{l}\text { Subjects who received deprenyl in DATATOP trial did } \\
\text { not have sustained benefits after re-initiation of this } \\
\text { therapy. The investigators stated that this result may have } \\
\text { been due (in part) to the more severe impairment of } \\
\text { deprenyl-assigned subjects at baseline, who originally } \\
\text { received deprenyl in the DATATOP trial but were more } \\
\text { likely to require levodopa during this extended period of } \\
\text { observation. } \\
\text { The second limitation is that the second period was an } \\
\text { open-label period. }\end{array}$ \\
\hline & SINDEPAR & $\begin{array}{l}\text { SWD (14 } \\
\text { months, with }\end{array}$ & 101 early-stage, & The change in & Positive & Inconclusive & The two-month period 2 was considered too short to \\
\hline
\end{tabular}




\begin{tabular}{|c|c|c|c|c|c|c|c|}
\hline & $\begin{array}{l}\text { Olanow et } \\
\text { al.,1995 [51] }\end{array}$ & $\begin{array}{l}2 \text { months of } \\
\text { WO) }\end{array}$ & untreated patients & UPDRS & & & eliminate symptomatic effects \\
\hline & $\begin{array}{l}\text { Pålhagen et al., } \\
1998 \text { [52] }\end{array}$ & $\begin{array}{l}\text { SWD ( } 2 \\
\text { months of } \\
\text { WO after } \\
\text { levodopa } \\
\text { therapy } \\
\text { became } \\
\text { necessary) }\end{array}$ & $\begin{array}{l}157 \text { early-stage, } \\
\text { untreated patients }\end{array}$ & $\begin{array}{l}\text { The change in } \\
\text { UPDRS }\end{array}$ & Positive & Inconclusive & $\begin{array}{l}\text { Many consider the washout period to have been too short } \\
\text { to provide conclusive evidence of neuroprotection, as the } \\
\text { observed benefits could also have been explained by a } \\
\text { long-term symptomatic effect (Shoulson et al, 2002) }\end{array}$ \\
\hline & $\begin{array}{l}\text { Pålhagen et al., } \\
2006 \text { [53] }\end{array}$ & LT (7 years) & $\begin{array}{l}157 \text { early-stage, } \\
\text { untreated patients }\end{array}$ & $\begin{array}{l}\text { The change in } \\
\text { UPDRS }\end{array}$ & Inconclusive & Negative & $\begin{array}{l}\text { UPDRS scores were significantly lower in the selegiline } \\
\text { group after } 48 \text { months but not after } 60 \text { months. Data on } \\
\text { UPDRS scores were only available for } 19 \text { patients in the } \\
\text { selegiline arm and } 28 \text { on placebo; thus, the results were } \\
\text { hard to interpret }\end{array}$ \\
\hline $\begin{array}{l}\text { Tocopherol } \\
\text { (vitamin E) }\end{array}$ & $\begin{array}{l}\text { DATATOP } \\
\text { (PSG), } 1989 \\
{[49]}\end{array}$ & LT (2 years) & $\begin{array}{l}800 \text { early-stage, } \\
\text { untreated patients }\end{array}$ & $\begin{array}{l}\text { The need for } \\
\text { symptomatic } \\
\text { treatment }\end{array}$ & Negative & Negative & $\begin{array}{l}\text { It is not clear whether the benefit of treatment was due to } \\
\text { a symptomatic effect alone or to a combination of } \\
\text { symptomatic and DM effects }\end{array}$ \\
\hline \multirow[t]{2}{*}{ Rasagiline } & $\begin{array}{l}\text { TEMPO (PSG), } \\
2004[35]\end{array}$ & $\begin{array}{l}\text { DS (26 } \\
\text { weeks) }\end{array}$ & $\begin{array}{l}404 \text { early-stage, } \\
\text { untreated patients }\end{array}$ & $\begin{array}{l}\text { The change in } \\
\text { UPDRS }\end{array}$ & Positive & Inconclusive & $\begin{array}{l}\text { Between } 61 \% \text { and } 65 \% \text { of the patients completed the full } \\
\text { follow-up period, and LOCF was used to compute data for } \\
\text { the remainder. LOCF may not have been appropriate for } \\
\text { all the patients who end-pointed along the way }\end{array}$ \\
\hline & $\begin{array}{l}\text { ADAGIO, } \\
\text { Olanow et al., } \\
2009[39]\end{array}$ & $\begin{array}{l}\text { DS (72 } \\
\text { weeks) }\end{array}$ & $\begin{array}{l}1176 \text { early-stage, } \\
\text { untreated patients } \\
\text { (less than } 18 \text { months } \\
\text { after a documented } \\
\text { diagnosis) }\end{array}$ & $\begin{array}{l}\text { The change in } \\
\text { UPDRS }\end{array}$ & Positive & Inconclusive & $\begin{array}{l}\text { Rasagiline } 1 \mathrm{mg} \text { reached significance in all primary end } \\
\text { points but rasagiline } 2 \mathrm{mg} \text { did not. The small overall } \\
\text { change in UPDRS and the lack of a dose response } \\
\text { complicated the interpretation of clinical relevance }\end{array}$ \\
\hline \multirow[t]{2}{*}{ Co-Q10 } & $\begin{array}{l}\text { Shults et al., } \\
2002 \text { [41] }\end{array}$ & $\begin{array}{l}\text { LT (16 } \\
\text { months) }\end{array}$ & $\begin{array}{l}80 \text { early-stage, } \\
\text { untreated patients }\end{array}$ & $\begin{array}{l}\text { The change in } \\
\text { UPDRS }\end{array}$ & Positive & Inconclusive & $\begin{array}{l}\text { It is not clear whether the benefit of treatment was due to } \\
\text { a symptomatic effect alone or to a combination of } \\
\text { symptomatic and DM effects. } \\
\text { This was a small study, and the effect size was not } \\
\text { determined }\end{array}$ \\
\hline & $\begin{array}{l}\text { NINDS NETPD } \\
\text { investigators, } \\
2007[54]\end{array}$ & $\begin{array}{l}\text { FS (12 } \\
\text { months) }\end{array}$ & $\begin{array}{l}213 \text { early-stage, } \\
\text { untreated patients } \\
\text { (less than } 5 \text { years } \\
\text { after diagnosis) }\end{array}$ & $\begin{array}{l}\text { The change in } \\
\text { UPDRS }\end{array}$ & Non-futile & Negative & \\
\hline
\end{tabular}




\begin{tabular}{|c|c|c|c|c|c|c|c|}
\hline & $\begin{array}{l}\text { NCT00740714 } \\
{[55]}\end{array}$ & $\begin{array}{l}\text { LT (16 } \\
\text { months) }\end{array}$ & $\begin{array}{l}600 \text { early stage, } \\
\text { untreated patients } \\
\text { (less than } 5 \text { years } \\
\text { after diagnosis) }\end{array}$ & $\begin{array}{l}\text { The change in } \\
\text { UPDRS }\end{array}$ & Negative & Negative & Early termination. Results not yet published \\
\hline \multirow[t]{2}{*}{ Ropinirole } & $\begin{array}{l}\text { REAL-PET, } \\
\text { Whone et al., } \\
2003 \text { [42] }\end{array}$ & $\begin{array}{l}\text { LT } \\
\text { (2 years) }\end{array}$ & $\begin{array}{l}186 \text { early-stage, } \\
\text { untreated patients }\end{array}$ & $\begin{array}{l}\text { Surrogate } \\
\text { imaging } \\
\text { marker }\end{array}$ & $\begin{array}{l}\text { Less change } \\
\text { in striatal F- } \\
\text { dopa with } \\
\text { ropinirole } \\
\text { versus L-dopa }\end{array}$ & Negative & $\begin{array}{l}\text { Absence of a placebo arm, possible use of L-dopa or } \\
\text { ropinirole influenced the striatal decarboxylase activity }\end{array}$ \\
\hline & $\begin{array}{l}\text { NCT01485172 } \\
{[56]}\end{array}$ & LT & $\begin{array}{l}186 \text { early-stage, } \\
\text { treated PD (limited } \\
\text { prior exposure to } \\
\text { low or moderate } \\
\text { doses of L-DOPA: } \\
\text { up to } 3 \text { months in } \\
\text { total) }\end{array}$ & $\begin{array}{l}\text { The change in } \\
\text { UPDRS motor } \\
\text { score }\end{array}$ & \multicolumn{3}{|c|}{ Results not published } \\
\hline \multirow[t]{2}{*}{ Pramipexole } & $\begin{array}{l}\text { CALM-PD } \\
\text { (PSG), 2000 \& } \\
2002[57,58]\end{array}$ & $\begin{array}{l}\text { LT } \\
\text { (23.5 months) }\end{array}$ & $\begin{array}{l}301 \text { early PD } \\
\text { patients who require } \\
\text { dopaminergic } \\
\text { therapy for } \\
\text { emerging disability }\end{array}$ & $\begin{array}{l}\text { Surrogate } \\
\text { imaging } \\
\text { marker }\end{array}$ & $\begin{array}{l}\text { Less change } \\
\text { in striatal } \\
\beta \text {-CIT with } \\
\text { pramipexole } \\
\text { versus } \\
\text { L-dopa }\end{array}$ & Negative & $\begin{array}{l}\text { Firm conclusions were precluded by the absence of a } \\
\text { placebo arm, the lack of a clinical correlate, and the } \\
\text { potential pharmacodynamic impact of chronic dopamine } \\
\text { treatment on the primary outcome measure. }\end{array}$ \\
\hline & $\begin{array}{l}\text { PROUD, } \\
\text { Schapira et al., } \\
2009 \& 2010 \& \\
2013[59,60, \\
61]\end{array}$ & $\begin{array}{l}\text { DS (15 } \\
\text { months) }\end{array}$ & $\begin{array}{l}535 \text { early-stage, } \\
\text { untreated patients } \\
\text { (diagnosed within } \\
\text { the previous } 3 \\
\text { years) }\end{array}$ & $\begin{array}{l}\text { The change in } \\
\text { UPDRS }\end{array}$ & Negative & Negative & $\begin{array}{l}\text { The DAT results also failed to evidence a neuroprotective } \\
\text { effect of pramipexole }\end{array}$ \\
\hline L-dopa & $\begin{array}{l}\text { Dopa } \\
\text { ELLDOPA, } \\
\text { Fahn et al., } \\
2004[10]\end{array}$ & $\begin{array}{l}\text { SWD (42 } \\
\text { weeks) }\end{array}$ & $\begin{array}{l}361 \text { early-stage, } \\
\text { untreated patients }\end{array}$ & $\begin{array}{l}\text { The change in } \\
\text { UPDRS }\end{array}$ & $\begin{array}{l}\text { Positive for } \\
\text { UPDRS }\end{array}$ & Inconclusive & $\begin{array}{l}\text { The short WO period and the well-established "long } \\
\text { duration L-dopa effect" prevent any firm conclusions } \\
\text { from being drawn }\end{array}$ \\
\hline Riluzole & $\begin{array}{l}\text { Jankovic et al., } \\
2002[62]\end{array}$ & $\begin{array}{l}\text { SWD (6 } \\
\text { months) }\end{array}$ & $\begin{array}{l}20 \text { early-stage, } \\
\text { untreated patients }\end{array}$ & $\begin{array}{l}\text { The change in } \\
\text { UPDRS }\end{array}$ & Negative & Negative & $\begin{array}{l}\text { Given the exploratory nature of the design and the small } \\
\text { sample size, it was not possible to determine whether } \\
\text { riluzole affected the natural history of PD }\end{array}$ \\
\hline
\end{tabular}




\begin{tabular}{|c|c|c|c|c|c|c|c|}
\hline CEP-1347 & {$[44]$} & $\begin{array}{l}\text { LT } \\
\text { (21.4 months) }\end{array}$ & $\begin{array}{l}806 \text { early-stage, } \\
\text { untreated patients }\end{array}$ & $\begin{array}{l}\text { The need for } \\
\text { symptomatic } \\
\text { treatment }\end{array}$ & Negative & Negative & Early termination (futile) \\
\hline TCH346 & $\begin{array}{l}\text { Olanow et al., } \\
2006 \text { [63] }\end{array}$ & $\begin{array}{l}\text { SWD (18 } \\
\text { months) }\end{array}$ & $\begin{array}{l}301 \text { early-stage, } \\
\text { untreated patients }\end{array}$ & $\begin{array}{l}\text { The need for } \\
\text { symptomatic } \\
\text { treatment }\end{array}$ & Negative & Negative & $\begin{array}{l}\text { The doses of TCH346 selected for testing might be a } \\
\text { problem, as many neuroprotective drugs exhibit inverted } \\
\text { U-shaped curves in which higher- or lower-than-optimum } \\
\text { concentrations are ineffective }\end{array}$ \\
\hline GDNF & $\begin{array}{l}\text { PSG PRECEPT } \\
\text { investigators, } \\
2007[46]\end{array}$ & $\begin{array}{l}\text { LT } \\
\text { open-label } \\
\text { trial }\end{array}$ & $\begin{array}{l}\text { Treated patients } \\
\text { with advanced } \\
\text { idiopathic PD }\end{array}$ & $\begin{array}{l}\text { The change in } \\
\text { UPDRS }\end{array}$ & Negative & Negative & $\begin{array}{l}\text { The patients in the active arm had more severe disease and } \\
\text { received lower doses than in the positive open trials. The } \\
\text { infusion methods and catheter diameter could have } \\
\text { potentially given different physiological results }\end{array}$ \\
\hline Minocycline & $\begin{array}{l}\text { NINDS NETPD } \\
\text { investigators, } \\
2006[64]\end{array}$ & $\begin{array}{l}\text { FS (12 } \\
\text { months) }\end{array}$ & $\begin{array}{l}200 \text { early-stage, } \\
\text { untreated patients } \\
\text { (less than } 5 \text { years } \\
\text { after diagnosis) }\end{array}$ & $\begin{array}{l}\text { The change in } \\
\text { UPDRS from } \\
\text { baseline to } \\
\text { either the time } \\
\text { when there } \\
\text { was sufficient } \\
\text { disability to } \\
\text { warrant } \\
\text { symptomatic } \\
\text { therapy for PD } \\
\text { or } 12 \text { months, } \\
\text { whichever } \\
\text { came first. }\end{array}$ & Non-futile & Negative & $\begin{array}{l}\text { Phase II futility trials are designed to determine whether } \\
\text { the agent is actually effective in slowing the clinical } \\
\text { progression of PD and hence cannot be used clinically for } \\
\text { treatment in PD, based on the results of this study. } \\
\text { Tooth discoloration was frequent in the minocycline arm } \\
\text { and hence this was added to the informed consent form } \\
\text { during the trial. It is possible that tooth discoloration could } \\
\text { have unblinded the trial, with the potential over-estimation } \\
\text { of the positive results for minocycline }\end{array}$ \\
\hline Creatine & $\begin{array}{l}\text { NINDS NETPD } \\
\text { investigators, } \\
2006[64]\end{array}$ & $\begin{array}{l}\text { FS (12 } \\
\text { months) }\end{array}$ & $\begin{array}{l}200 \text { early-stage } \\
\text { patients }\end{array}$ & $\begin{array}{l}\text { The change in } \\
\text { UPDRS from } \\
\text { baseline up } \\
\text { until either } \\
\text { sufficient } \\
\text { disability to } \\
\text { warrant } \\
\text { symptomatic } \\
\text { therapy for PD } \\
\text { or } 12 \text { months, } \\
\text { whichever } \\
\text { came first. }\end{array}$ & Positive & Inconclusive & $\begin{array}{l}\text { Additional factors must be weighed up before performing } \\
\text { Phase III trials for creatine, including safety, tolerability, } \\
\text { activity, cost, and availability of these two agents relative } \\
\text { to others in clinical development for PD }\end{array}$ \\
\hline
\end{tabular}




\begin{tabular}{|c|c|c|c|c|c|c|c|}
\hline $\begin{array}{l}\text { Creatine } \\
\text { monohydrate }\end{array}$ & $\begin{array}{l}\text { NINDS NETPD } \\
\text { investigators, } \\
2015 \text { [45] }\end{array}$ & $\begin{array}{l}\mathrm{FS}+\mathrm{LT}(6 \\
\text { years })\end{array}$ & $\begin{array}{l}1741 \text { early-stage } \\
\text { patients (within } 5 \\
\text { years of diagnosis) } \\
\text { treated for less than } \\
2 \text { years. }\end{array}$ & $\begin{array}{l}\text { Overall } \\
\text { statistical test } \\
\text { (Modified } \\
\text { Rankin Scale, } \\
\text { Symbol Digit } \\
\text { Modalities } \\
\text { Test, PDQ-39 } \\
\text { Summary } \\
\text { Index, Schwab } \\
\text { and England } \\
\text { Activities of } \\
\text { Daily Living } \\
\text { scale, and } \\
\text { ambulatory } \\
\text { capacity) }\end{array}$ & Negative & Negative & $\begin{array}{l}\text { The trial was terminated early for futility, based on the } \\
\text { results of a planned interim analysis of participants } \\
\text { enrolled at least } 5 \text { years prior to the date of the analysis } \\
(\mathrm{n}=955) \text {. }\end{array}$ \\
\hline $\begin{array}{l}\text { PYM50028 } \\
\text { (Cogane) }\end{array}$ & $\begin{array}{l}\text { NCT01060878 } \\
{[65]}\end{array}$ & $\begin{array}{l}\text { LT (28 } \\
\text { weeks) }\end{array}$ & $\begin{array}{l}425 \text { early stage, } \\
\text { untreated patients } \\
\text { (diagnosed in the } 2 \\
\text { years prior to } \\
\text { screening) }\end{array}$ & $\begin{array}{l}\text { The change in } \\
\text { UPDRS }\end{array}$ & \multicolumn{3}{|c|}{ Detailed results not yet published } \\
\hline Immunophilin & $\begin{array}{l}\text { NINDS NETPD } \\
\text { Investigators } \\
2006 \text { [66] }\end{array}$ & $\begin{array}{l}\text { FS (12 } \\
\text { months) }\end{array}$ & $\begin{array}{l}213 \text { early-stage, } \\
\text { untreated patients } \\
\text { (less than } 5 \text { years } \\
\text { after diagnosis) }\end{array}$ & $\begin{array}{l}\text { The change in } \\
\text { UPDRS }\end{array}$ & $\begin{array}{l}\text { Positive for a } \\
\text { further phase } \\
\text { III trial }\end{array}$ & Inconclusive & $\begin{array}{l}\text { Phase II futility trials are designed to determine whether } \\
\text { the agent is actually effective in slowing the clinical } \\
\text { progression of PD and hence cannot be used clinically for } \\
\text { treatment in PD, based on the results of this study }\end{array}$ \\
\hline Paliroden & $\begin{array}{l}\text { NCT00220272 } \\
{[67]}\end{array}$ & LT (2 years) & $\begin{array}{l}183 \text { early-stage, } \\
\text { treated (less than } 3 \\
\text { years after } \\
\text { diagnosis.) }\end{array}$ & $\begin{array}{l}\text { Change in } \\
\text { average (left } \\
\text { and right) } \\
\text { putamen } 18 \mathrm{~F}- \\
\text { Dopa influx } \\
\text { constant }(\mathrm{Ki}) \\
\text { from baseline } \\
\text { to two-year } \\
\text { 18F-Dopa PET }\end{array}$ & \multicolumn{3}{|c|}{ Results not published } \\
\hline AAV2-neurturin & $\begin{array}{l}\text { Marks et al., } \\
2010[47]\end{array}$ & $\begin{array}{l}\text { LT } \\
\text { (12 months) }\end{array}$ & $\begin{array}{l}58 \text { late-stage, treated } \\
\text { patients }\end{array}$ & $\begin{array}{l}\text { The change in } \\
\text { UPDRS }\end{array}$ & Negative & Negative & $\begin{array}{l}\text { A subsequent trial administered AAV2-neurturin to the } \\
\text { putamen plus SNc. }\end{array}$ \\
\hline
\end{tabular}




\begin{tabular}{|c|c|c|c|c|c|c|c|}
\hline \multirow[t]{2}{*}{$\begin{array}{l}\text { GM1 } \\
\text { ganglioside }\end{array}$} & $\begin{array}{l}\text { Schneider } \text { et } \\
\text { al.,2010 [68] }\end{array}$ & $\begin{array}{l}\text { Simple short- } \\
\text { term } 16 \\
\text { weeks, } \\
\text { open-label } \\
5 \text { years }\end{array}$ & $\begin{array}{l}26 \text { moderate-stage, } \\
\text { treated patients }\end{array}$ & $\begin{array}{l}\text { Changes in } \\
\text { UPDRS }\end{array}$ & $\begin{array}{l}\text { Practically } \\
\text { defined OFF } \\
\text { scores at } 5 \\
\text { years same } \\
\text { or better than } \\
\text { at baseline }\end{array}$ & Inconclusive & $\begin{array}{l}\text { The randomized period was only } 16 \text { weeks long, and the } \\
\text { rest of the study was open-label }\end{array}$ \\
\hline & $\begin{array}{l}\text { Schneider et al., } \\
2013[69]\end{array}$ & $\begin{array}{l}\text { DS }(120 \\
\text { weeks })\end{array}$ & $\begin{array}{l}177 \text { early-stage, } \\
\text { treated patients }(6 \\
\text { months after } \\
\text { diagnosis) }\end{array}$ & $\begin{array}{l}\text { The change in } \\
\text { UPDRS }\end{array}$ & $\begin{array}{l}\text { Positive for } \\
\text { symptomatic } \\
\text { effects }\end{array}$ & Inconclusive & A small study that provided little evidence of DM effects \\
\hline $\begin{array}{l}\text { Mitoquinone } \\
\text { (MitoQ) }\end{array}$ & $\begin{array}{l}\text { Snow et al. } \\
2010[43]\end{array}$ & $\begin{array}{l}\text { LT } \\
\text { (12 months) }\end{array}$ & $\begin{array}{l}128 \text { early-stage, } \\
\text { untreated patients }\end{array}$ & $\begin{array}{l}\text { The change in } \\
\text { UPDRS }\end{array}$ & Negative & Negative & $\begin{array}{l}\text { Methodological problems (including inadequate sample } \\
\text { size) and the underlying severity of DA deficiency could } \\
\text { potentially counter any benefit from a neuroprotective } \\
\text { agent. Possibly insufficient brain penetration of MitoQ }\end{array}$ \\
\hline Pioglitazone & $\begin{array}{l}\text { NINDS NETPD } \\
\text { investigators, } \\
2015[70]\end{array}$ & $\begin{array}{l}\text { LT and FS } \\
\text { (44 weeks) }\end{array}$ & $\begin{array}{l}210 \text { early-stage, } \\
\text { treated patients (on } \\
\text { a stable regimen of } \\
1 \mathrm{mg} / \text { day rasagiline } \\
\text { or } 10 \mathrm{mg} / \text { day } \\
\text { selegiline) }\end{array}$ & $\begin{array}{l}\text { The change in } \\
\text { UPDRS }\end{array}$ & Negative & Negative & $\begin{array}{l}\text { The findings suggest that the studied doses of pioglitazone } \\
\text { were unlikely to modify progression in early-stage PD. } \\
\text { Further study of pioglitazone in a larger trial is not } \\
\text { recommended }\end{array}$ \\
\hline $\begin{array}{l}\mathrm{N}- \\
\text { Acetylcysteine }\end{array}$ & $\begin{array}{l}\text { NCT01470027 } \\
\text { [71] }\end{array}$ & $\begin{array}{l}\text { LT ( } 30 \text { days, } \\
3 \text { groups) }\end{array}$ & $\begin{array}{l}50 \text { patients (PD } \\
\text { duration less than } 15 \\
\text { years), untreated } \\
\text { except for } \\
\text { anticholinergic } \\
\text { agents }\end{array}$ & $\begin{array}{l}\text { Change in } \\
\text { brain cerebral } \\
\text { glutathione } \\
\text { levels on } \\
\text { proton MRS }\end{array}$ & Results not ye & ublished & \\
\hline \multirow[t]{3}{*}{ Exenatide } & $\begin{array}{l}\text { Aviles-Olmos et } \\
\text { al., } 2013 \text { [72] }\end{array}$ & $\begin{array}{l}\text { LT } \\
\text { (60 weeks) }\end{array}$ & \multirow[t]{2}{*}{$\begin{array}{l}45 \text { moderate } \\
\text { severity, treated } \\
\text { patients (more than } \\
5 \text { years since the } \\
\text { diagnosis) }\end{array}$} & $\begin{array}{l}\text { Change in } \\
\text { MDS-UPDRS }\end{array}$ & $\begin{array}{l}\text { Positive for } \\
\text { symptomatic } \\
\text { effects }\end{array}$ & Inconclusive & \multirow[t]{2}{*}{ A single-blind, proof-of-concept trial } \\
\hline & $\begin{array}{l}\text { Aviles-Olmos et } \\
\text { al., } 2014\end{array}$ & $\begin{array}{l}\text { SWD }(24 \\
\text { months })\end{array}$ & & $\begin{array}{l}\text { Change in } \\
\text { MDS-UPDRS }\end{array}$ & Positive & Inconclusive & \\
\hline & $\begin{array}{l}\text { NCT01971242 } \\
{[73]}\end{array}$ & $\begin{array}{l}\text { LT (60 } \\
\text { weeks) }\end{array}$ & $\begin{array}{l}60 \text { early-stage, } \\
\text { treated patients }\end{array}$ & $\begin{array}{l}\text { Change in } \\
\text { MDS-UPDRS }\end{array}$ & \multicolumn{3}{|c|}{ Results not yet published } \\
\hline
\end{tabular}




\begin{tabular}{|c|c|c|c|c|c|c|c|}
\hline \multirow[t]{2}{*}{ Deferiprone } & Devos et al. [26] & $\begin{array}{l}\text { DS (12 } \\
\text { months) }\end{array}$ & $\begin{array}{l}40 \text { early-stage, } \\
\text { treated patients } \\
\text { (mainly less than } 2 \\
\text { to } 3 \text { years since } \\
\text { disease onset and } \\
\text { never more than } 4 \\
\text { years) }\end{array}$ & $\begin{array}{l}\text { The change in } \\
\text { UPDRS }\end{array}$ & Positive & $\begin{array}{l}\text { Initial evidence to } \\
\text { be confirmed }\end{array}$ & \\
\hline & $\begin{array}{l}\text { NCT02655315 } \\
\text { FAIRPARK-II } \\
\text { [74] }\end{array}$ & $\begin{array}{l}\text { SWD (40 } \\
\text { weeks) }\end{array}$ & $\begin{array}{l}338 \text { early-stage, } \\
\text { untreated patients } \\
\text { (disease duration } \\
\text { less than } 18 \text { months) }\end{array}$ & $\begin{array}{l}\text { Change in } \\
\text { MDS-UPDRS }\end{array}$ & \multicolumn{3}{|c|}{ Results not yet published } \\
\hline $\begin{array}{l}\text { Transdermal } \\
\text { nicotine }\end{array}$ & $\begin{array}{l}\text { NCT01560754 } \\
{[75]}\end{array}$ & $\begin{array}{l}\text { SWD } \\
\text { (14months) }\end{array}$ & $\begin{array}{l}160 \text { early-stage } \\
\text { untreated patients } \\
\text { (disease duration } \\
\text { less than } 18 \text { months) }\end{array}$ & $\begin{array}{l}\text { The change in } \\
\text { the total } \\
\text { UPDRS (part } \\
\text { I-III) score }\end{array}$ & \multicolumn{3}{|c|}{ Results not yet published } \\
\hline $\begin{array}{l}\text { Isradipine } \\
\text { sris }\end{array}$ & $\begin{array}{l}\text { NCT02168842 } \\
{[76]}\end{array}$ & $\begin{array}{l}\text { LT ( } 36 \\
\text { months) }\end{array}$ & $\begin{array}{l}336 \text { early-stage } \\
\text { treated }\end{array}$ & $\begin{array}{l}\text { The change in } \\
\text { the total } \\
\text { UPDRS (part } \\
\text { I-III) score }\end{array}$ & \multicolumn{3}{|c|}{ Results not yet published } \\
\hline \multicolumn{8}{|c|}{ Non-pharmacological studies } \\
\hline Aerobic walking & $\begin{array}{l}\text { Uc et al., } 2014 \\
{[77]}\end{array}$ & $\begin{array}{l}\text { Two-cluster } \\
\text { RCT (6 } \\
\text { months) }\end{array}$ & $\begin{array}{l}60 \text { early-stage, } \\
\text { treated patients }\end{array}$ & $\begin{array}{l}\text { Trails A and B } \\
\text { task }\end{array}$ & $\begin{array}{l}\text { Positive on } \\
\text { safety and } \\
\text { tolerability }\end{array}$ & Inconclusive & $\begin{array}{l}\text { Although physical exercise improves motor aspects of } \\
\text { Parkinson's disease (PD), it is not clear whether it may } \\
\text { also have a neuroprotective effect. }\end{array}$ \\
\hline Physical exercise & $\begin{array}{l}\text { Frazzitta } \text { et al., } \\
2015 \text { [78] }\end{array}$ & LT (2 years) & $\begin{array}{l}40 \text { early-stage, } \\
\text { untreated with anti- } \\
\text { parkinsonian } \\
\text { medication or } \\
\text { having received } \\
\text { medication, for less } \\
\text { than two years, } \\
\text { medication- } \\
\text { responsive without } \\
\text { fluctuations. }\end{array}$ & $\begin{array}{l}\text { The change in } \\
\text { UPDRS II, } \\
\text { UPDRS III, } \\
\text { TUG, and } \\
\text { PDDS } \\
\text { L-dopa } \\
\text { equivalent }\end{array}$ & Positive & Inconclusive & $\begin{array}{l}\text { It is not clear whether the benefit of treatment was due to } \\
\text { a symptomatic effect alone or to a combination of } \\
\text { symptomatic and DM effects }\end{array}$ \\
\hline
\end{tabular}


DM: disease-modifying effect; GDNF: glial-derived neurotrophic factor; Co-Q10: co-enzyme Q10; DA: dopaminergic; OFF: off-state; PSG: Parkinson Study Group; LT: long-term; SWD: simple withdrawal; WO: washout; DS: delayed start; FS: futility study; UPDRS: Unified Parkinson's Disease Rating; MDS: Movement Disorders Society; MRS: magnetic resonance spectroscopy; MRI: magnetic resonance imaging; SN: substantia nigra; LOCF: last observation carried forward; TUG: Timed Up-and-Go test; PDDS: PD Disability Scale; RCT: randomized, controlled trial. Treated PD: dopaminergic therapy. Early PD: Hoehn and Yahr Scale stage I or II. All the cited clinical trials are listed at http://www.ncbi.nlm.nih.gov/ and/or https://clinicaltrials.gov. 
S-Table 2. Strengths and limitations of clinical trial designs that can be used to assess neuroprotection in PD. WD: withdrawal; RWD: randomized withdrawal; DS: delayed-start. Designs in bold type have already been used to assess neuroprotection in PD. Designs in white type are new designs not previously applied to PD and that may be of value for studying disease modification in this field. 


\begin{tabular}{|c|c|c|c|c|c|c|c|c|c|}
\hline \multirow{2}{*}{$\begin{array}{c}\text { Clinical } \\
\text { trial } \\
\text { design }\end{array}$} & \multirow{2}{*}{$\begin{array}{l}\text { Futility design: } \\
\text { non-superiority } \\
\text { study }\end{array}$} & \multirow[b]{2}{*}{$\begin{array}{l}\text { Simple withdrawal } \\
\text { (SWD) }\end{array}$} & \multicolumn{3}{|c|}{ Randomized withdrawal (RWD) } & \multirow[b]{2}{*}{$\begin{array}{l}\text { Delayed-start } \\
\text { (DS) }\end{array}$} & \multicolumn{3}{|c|}{ Long-term study } \\
\hline & & & $\begin{array}{l}\text { Randomization of } \\
\text { responders for } \\
\text { period } 2\end{array}$ & $\begin{array}{l}\text { Randomization } \\
\text { of all patients } \\
\text { for period } 2\end{array}$ & $\begin{array}{l}\text { Randomization } \\
\text { for period 1:3 } \\
\text { groups }\end{array}$ & & Strict protocol & Open protocol & $\begin{array}{l}\text { Simple long-term } \\
\text { study }\end{array}$ \\
\hline Patients & $\begin{array}{c}\text { Treated or de novo } \\
\text { patients }\end{array}$ & \multicolumn{7}{|c|}{ De novo: treatment-naïve and newly diagnosed } & $\begin{array}{l}\text { Treated patients at } \\
\text { any stage of the } \\
\text { disease }\end{array}$ \\
\hline \multirow[t]{3}{*}{ Strengths } & \multirow{3}{*}{$\begin{array}{l}\text { - More rapid } \\
\text { identification of } \\
\text { agents that should } \\
\text { not be candidates } \\
\text { for larger, } \\
\text { expensive Phase } \\
\text { III trials }\end{array}$} & \multicolumn{5}{|c|}{ Ability to differentiate between short-term and long-term effects } & \multicolumn{3}{|c|}{$\begin{array}{l}\text {-Long-term side effects of a treatment on various and variable } \\
\text { disease parameter. } \\
\text {-Assessment of safety }\end{array}$} \\
\hline & & \multirow{2}{*}{$\begin{array}{l}\text {-Simple design with little } \\
\text { bias } \\
\text { - Less expensive than RWD } \\
\text { and DS designs } \\
\text {-No confounding effects of } \\
\text { symptomatic medication, } \\
\text { compared with the DS } \\
\text { design. }\end{array}$} & \multicolumn{2}{|c|}{$\begin{array}{l}\text { - Shorter time on placebo, compared } \\
\text { with the simple withdrawal design. } \\
\\
\text { - No unblinding concerns during } \\
\text { period } 1\end{array}$} & $\begin{array}{l}\text { - Evidence of } \\
\text { a treatment } \\
\text { effect will be } \\
\text { more reliable } \\
\text { than in the two } \\
\text { other } \\
\text { randomized }\end{array}$ & $\begin{array}{l}\text { - Fewer ethical } \\
\text { constraints on the } \\
\text { length of the } \\
\text { placebo period than } \\
\text { the WD design }\end{array}$ & $\begin{array}{l}\text { - Easier to set up } \\
\text { and analyze than an } \\
\text { open protocol }\end{array}$ & $\begin{array}{l}\text { - Fewer drop outs } \\
\text { in period } 1 \text { than in a } \\
\text { strict protocol } \\
\text {-The length of } \\
\text { period } 1 \text { is adapted } \\
\text { to suit each patient }\end{array}$ & \multirow[t]{2}{*}{$\begin{array}{l}\text { - Easier to recruit } \\
\text { patients } \\
\text { - Simple trial } \\
\text {-Broader endpoints } \\
\text { because all disease } \\
\text { stages are } \\
\text { represented }\end{array}$} \\
\hline & & & $\begin{array}{l}\text {-More selective } \\
\text { than the } \\
\text { randomization of } \\
\text { all patients for } \\
\text { period } 2\end{array}$ & $\begin{array}{l}\text { - Evidence of a } \\
\text { treatment effect } \\
\text { will be more } \\
\text { reliable than for } \\
\text { the } \\
\text { randomization } \\
\text { of responders } \\
\text { only. }\end{array}$ & $\begin{array}{l}\text { designs because } \\
\text { of the two } \\
\text { "control" groups }\end{array}$ & & \multicolumn{2}{|c|}{$\begin{array}{l}\text { - Period } 2 \text { can be long because all patients } \\
\text { are receiving symptomatic treatment (no } \\
\text { ethical concerns) } \\
\text {-Allows assessment of disease progression } \\
\text { from an early stage in the disease. } \\
\text { - Double-blind in period } 2 \text { (in contrast to } \\
\text { the simple long-term study followed by } \\
\text { an open-label extension) }\end{array}$} & \\
\hline \multirow[t]{2}{*}{$\begin{array}{c}\text { Weakness } \\
\text { es }\end{array}$} & $\begin{array}{l}\text {-Not possible to } \\
\text { evaluate treatment } \\
\text { efficacy }\end{array}$ & \multicolumn{5}{|c|}{$\begin{array}{l}\text {-This design cannot accurately track slow overall disease progression. } \\
\text {-One cannot be sure that a treatment benefit is present several years later } \\
\text { - A long-term study is required to characterize any side effects } \\
\text {-Difficult to recruit only early-stage, untreated patients }\end{array}$} & \multicolumn{3}{|c|}{ More drop-outs, due to the length of period 2} \\
\hline & $\begin{array}{l}\text {-Historical } \\
\text { controls can } \\
\text { induce bias in } \\
\text { comparisons. }\end{array}$ & $\begin{array}{l}\text {-Difficulty in finding the } \\
\text { ideal length of the periods } \\
\text { because of the } \\
\text { antiparkinsonian drugs' } \\
\text { pharmacokinetic and } \\
\text { pharmacodynamic effects. } \\
\text {-Risk of period } 1 \text { being too } \\
\text { short to see an effect on } \\
\text { disease progression }\end{array}$ & $\begin{array}{l}\text { - The need for a } \\
\text { large population, } \\
\text { since only } \\
\text { responders }\end{array}$ & $\begin{array}{l}\text {-All } \\
\text { responders and } \\
\text { non-responders } \\
\text { are confounded: } \\
\text { possible masked } \\
\text { effects of } \\
\text { treatment. }\end{array}$ & $\begin{array}{l}\text {-Expensive } \\
\text { and complex } \\
\text { trial }\end{array}$ & $\begin{array}{l}\text {-Symptomatic } \\
\text { effects can mask the } \\
\text { long-term effect of } \\
\text { the drug at the end } \\
\text { of the study (with a } \\
\text { high dosage) } \\
\text { - Complex and } \\
\text { expensive to set up } \\
\text { and analyze }\end{array}$ & $\begin{array}{l}\text {-More drop outs in } \\
\text { this strict protocol } \\
\text { because the length } \\
\text { of period } 1 \text { is } \\
\text { predetermined and } \\
\text { some patients may } \\
\text { need levodopa } \\
\text { before period } 2 \\
\text {-During period } 1 \text {, }\end{array}$ & $\begin{array}{l}\text {-Very complicated } \\
\text { to analyze, with a lot } \\
\text { of study variables } \\
\text {-Complex to set up } \\
\text { - The need for a } \\
\text { large population, in } \\
\text { order to compare the } \\
\text { two groups at the } \\
\text { same time (when }\end{array}$ & $\begin{array}{l}\text {-An intervention } \\
\text { associated with } \\
\text { benefits may not } \\
\text { reflect a truly } \\
\text { disease-modifying } \\
\text { effect, although } \\
\text { positive effects can } \\
\text { evidence slower } \\
\text { disease progression } \\
\text { because all patients }\end{array}$ \\
\hline
\end{tabular}




\begin{tabular}{|c|c|c|c|c|c|c|c|}
\hline $\begin{array}{l}\text { effective drug is } \\
\text { ineffective (in a } \\
\text { short study) } \\
\text { - One cannot } \\
\text { rule out } \\
\text { confounding } \\
\text { symptomatic } \\
\text { effects }\end{array}$ & \begin{tabular}{|l|}
-Balance between a long \\
period without symptomatic \\
treatment (to see long-term \\
effects) vs. ethical constraints \\
- Loss of blinding during \\
period 1 and period 2 \\
(possible nocebo effects)
\end{tabular} & $\begin{array}{l}\text { continue the trial } \\
\text {-Complex design } \\
\text { - No current } \\
\text { clinically } \\
\text { established } \\
\text { definition of a } \\
\text { responder in PD }\end{array}$ & \begin{tabular}{l}
\multicolumn{1}{c}{-Loss of } \\
blinding during \\
period 2
\end{tabular} & $\begin{array}{l}\text { - Long study : high } \\
\text { risk of drop-out in } \\
\text { the delayed-start } \\
\text { group } \\
\text {-Loss of blinding } \\
\text { during period } 1 \text { and } \\
2 \text { (an assessment } \\
\text { bias) }\end{array}$ & $\begin{array}{l}\text { some patients may } \\
\text { need rescue } \\
\text { medication at } \\
\text { different moments } \\
\text {-Difficulty in } \\
\text { determining the } \\
\text { length of period } 1\end{array}$ & $\begin{array}{l}\text { symptomatic } \\
\text { treatment is } \\
\text { required). }\end{array}$ & $\begin{array}{l}\text { are receiving } \\
\text { symptomatic } \\
\text { treatment }\end{array}$ \\
\hline
\end{tabular}




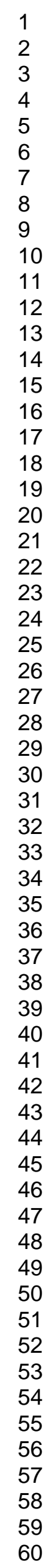

